\title{
Impact of Nutritional Intervention on Taste Perception-A Scoping Review
}

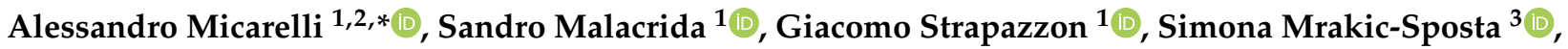 \\ Beatrice Micarelli ${ }^{2}$, Nicolò Alessandrini ${ }^{4}$, Valentina Carbini ${ }^{2}$, Sara Caputo ${ }^{5}$, Marika Falla ${ }^{1,6,+}(\mathbb{D})$ \\ and Marco Alessandrini ${ }^{7,+}$
}

1 Institute of Mountain Emergency Medicine, Eurac Research, 39100 Bolzano, Italy; sandro.malacrida@eurac.edu (S.M.); giacomo.strapazzon@eurac.edu (G.S.); marika.falla@unitn.it (M.F.)

2 ITER Center of Balance and Rehabilitation Research (ICBRR), UNITER ONLUS, 31010 Rome, Italy; beatricemicarelli@hotmail.it (B.M.); valentina.carbini@gmail.com (V.C.)

3 Institute of Clinical Physiology, National Research Council (CNR), 20162 Milan, Italy; simona.mrakicsposta@cnr.it

4 Faculty of Philosophy, University of Rome Tor Vergata, 00133 Rome, Italy; dcapoccia@icloud.com

5 L-Nutra Italia S.r.l., 20122 Milan, Italy; scaputo@l-nutra.com

6 Center for Mind/Brain Sciences, CIMeC, University of Trento, 38068 Rovereto, Italy

7 ENT Unit, Department of Clinical Sciences and Translational Medicine, University of Rome Tor Vergata, 00133 Rome, Italy; malessandrini63@gmail.com

* Correspondence: alessandromicarelli@yahoo.it

+ These authors have contributed equally to this work.

check for updates

Citation: Micarelli, A.; Malacrida, S.; Strapazzon, G.; Mrakic-Sposta, S.; Micarelli, B.; Alessandrini, N.; Carbini, V.; Caputo, S.; Falla, M.; Alessandrini, M. Impact of Nutritional Intervention on Taste Perception-A Scoping Review. Foods 2021, 10, 2747. https://doi.org/ $10.3390 /$ foods 10112747

Academic Editor: Luisa Torri

Received: 20 October 2021

Accepted: 8 November 2021

Published: 9 November 2021

Publisher's Note: MDPI stays neutral with regard to jurisdictional claims in published maps and institutional affiliations.

Copyright: (c) 2021 by the authors. Licensee MDPI, Basel, Switzerland. This article is an open access article distributed under the terms and conditions of the Creative Commons Attribution (CC BY) license (https:// creativecommons.org/licenses/by/ $4.0 /)$.
Abstract: The aim of the present scoping review was to evaluate the impact of experimental meal loads or observational diet changes/habits on taste tests in both healthy subjects and patients. A systematic search performed in PubMed, Scopus, and Institute for Scientific Information (ISI) Web of Science electronic databases retrieved, respectively 2981, 6258, and 7555 articles from January 2000 to December 2020. A total of 17 articles were included for full-text review. Literature results were stratified according to the observational/interventional approach, the involvement of healthy subjects or patients, the taste test, and the meal/dietary changes. The present scoping review reinforced the notions postulating that certain taste tests (for example focusing on fatty acid, salt, or sugar) might be specifically influenced by the nutritional intervention and that other ones might be susceptible to a wide span of changes beyond the extent of tastant included in the specific food changes. This could also depend on the inhomogeneity of literature trend: The short duration of the intervention or the random type of meal load, unsuitability of the taste test chosen, and the presence of underlying disorders. Future studies for a better comprehension of taste tests reliability in relation to specific food changes are thus to be fostered.

Keywords: taste test; food; gustatory perception; diet; taste threshold

\section{Introduction}

Taste is primarily a nutrient sensing system. The texture of the food and the rate at which it is eaten, have a profound effect on the time of orosensory exposure to foods and to satiation [1]. It has been established that slower eating leads to a longer exposure to taste [2-5]. Many studies suggest that the duration of the exposure to taste contributes significantly to the onset of satiation and the termination of a meal [6-8]. A longer duration of exposure to taste leads to earlier satiation [1]. A gut-brain signaling system has also been clearly demonstrated to influence taste responses to the consumption of food. The nucleus tractus solitarius (NTS) is the main entry point of the vagus nerve in the central nervous system, and thus, it receives afferent projections from most of the organs of the gastrointestinal (GI) tract [9]. In addition, the NTS also receives some cranial nerve afferents (i.e., facial and glossopharyngeal nerves) that convey extensive information on food texture, taste, smell, 
appearance, and palatability from the orosensory area, and conveys the ascending fibers ipsilaterally to the thalamus and insula, whereas some of them cross at the upper pons or midbrain level [10]. The gustatory system, therefore, has a predominately ipsilateral projection with some fibers crossing at the central level [10]. This system seems to respond rapidly to meal loads and to drive fast chemosensory-related reactions to the consumption of food [11]. On the other hand, chemosensory changes due to dietary habits are found to mainly rely on a wider network of areas including the hypothalamus and its sub-region responses, involved in the control of body energy homeostasis and its connections with NTS [11,12].

The comprehension of the reliability of testing taste-including both psychophysical and objective evaluations-appears of outmost relevance. Many clinical investigations have studied changes in the sense of taste in response to the meal load or to dietary habits as an effort to further cause changes along the pathways that support the extensive connections between taste and food intake. Within psychophysical evaluation techniques, there is a distinction between chemical (natural) (including the three-drop method [13,14], taste tablets and wafers [15,16], taste-strips [17-19], and the fatty acid threshold [20-22] or similar less-standardized methods [23-25]) and electrical testing tools (i.e., electrogustometry) $[26,27]$. The former techniques use basic taste solutions (sweet, sour, salty, bitter, and/or umami) to stimulate taste, and the latter techniques apply electrical currents to the surface of the tongue in order to elicit taste perceptions [20]. Both techniques suffer from the same shortcomings of psychophysical tests in general, which means that the patient must cooperate and must not be suffering from dementia. The main advantage of both tests is that they are quick and easy to perform [21] and have been used extensively in routine clinical practice and are currently accepted to be equally useful to measure gustatory function before and after any interventions [22]. Objective evaluation techniques-including gustatory event-related potentials [28,29], neuroimaging techniques (such as functional Magnetic Resonance Imaging [fMRI] and Positron Emission Tomography [PET]) [30-32], and the confocal microscopy [33,34] —are more difficult to perform [27] and require likewise patients' cooperation.

The aim of the present scoping review was to evaluate the impact of experimental meal loads or observational diet changes/habits on taste tests in both healthy subjects and patients.

\section{Scoping Review Methods}

The scoping review and the meta-analysis were conducted following the guidelines of the Preferred Reporting Items for Systematic Review and Meta-Analysis (PRISMA) extension for scoping reviews (PRISMA-ScR) [35].

\subsection{Eligibility Criteria}

The literature search was performed to identify studies evaluating taste changes in response to a nutritional intervention in the last 20 years: meal or nutrient loads, diet and food consumption habits, and fasting periods. The inclusion criteria (Table 1) of the search strategy design are categorized according to the broad Population-Concept-Context (PCC) mnemonic recommended for scoping reviews $[36,37]$.

The scoping review focuses on applications in experimental and clinical settings and on physiological research. Thus, studies on both adult healthy subjects and on patients were included. Studies were eligible only if psychophysical/objective, experimental/tailored objective taste tests were implemented after nutritional intervention, while studies investigating only behavioral, hedonic, and satiation aspects or mainly using questionnaires were excluded. 
The search was restricted to observational and interventional studies only involving humans and published in English in peer-reviewed journals. Abstracts, conference proceedings and reports, retrospective studies, expert opinions, letters to the Editor, commentaries, case reports, and reviews were excluded.

Table 1. Inclusion criteria for the scoping review summarized according to the Population-ConceptContext (PCC) mnemonic, recommended for scoping reviews [36,37].

\begin{tabular}{lll}
\hline Population & $\bullet$ & $\begin{array}{l}\text { Healthy and sick adults } \\
\text { Any Sex }\end{array}$ \\
\hline Concept & $\bullet$ & $\begin{array}{l}\text { Taste Tests changes in relation to interventional meal load or observational } \\
\text { dietary habits/changes }\end{array}$ \\
\hline Context & $\bullet$ & $\begin{array}{l}\text { Clinical and non-clinical settings, with focus on chemical sense science, } \\
\text { nutrition, and physiological research } \\
\text { Original peer-reviewed research articles (cross-sectional and interventional } \\
\text { study design), published in English in the last } 20 \text { years. }\end{array}$ \\
\hline
\end{tabular}

\subsection{Information Sources, Search Strategy, and Study Selection}

A systematic search was performed in PubMed, Scopus, and ISI Web of Science electronic databases to identify primary references from January 2000 to December 2020. The following search string was used: ("meal" OR "food" OR "nutrition" OR "fasting" OR "hunger" OR "diet" OR "calory" OR "energy consumption" OR "consumption" OR "intake" OR "satiation" OR "feeding" OR "eating" OR "nourishment" OR "sustenance") AND ("taste" OR "flavour" OR "gustatory" OR "test" OR "taste test" OR "taste perception" OR "gustatory perception" OR "taste sensitivity" OR "gustatory sensitivity" OR "taste strips" OR "chemosensory" OR "liking" OR "adverse reaction"). The database search was followed by a review of the citations from eligible studies. The studies were selected based on their title and their abstract using the online platform Rayyan [38]. The selected studies were read thoroughly to identify those suitable for inclusion in the scoping review.

\subsection{Data Extraction}

Two reviewers (A.M. and S.M.) independently extracted the demographic and experimental data from the selected studies. When they disagreed, they reviewed the papers together in order to reach joint conclusions. For each study, the following relevant information was extracted and summarized: The characteristics of the sample of subjects under evaluation, the taste tests, and possible neuropsychological comparators; the experimental setting/nutritional intervention of the investigated study group; and the main results of the study with focus on taste changes after the nutritional intervention.

\section{Results}

The literature search retrieved 2981 (Pubmed), 6258 (Scopus), and 7555 (ISI Web of Science) articles evaluating the impact of the nutritional intervention on taste perception. A total of 57 articles were retrieved for full-text review of which 17 were selected and included based on the inclusion criteria in the last 20 years (Figure 1).

The studies' results are summarized narratively and presented in Tables 2 and 3, according to the experimental design. 
Table 2. Observational studies included in the review.

\section{Main Objectives of the Study}

Taste Tests

Setting/Protocol and Other Outcome Measures

Taste Results

Taste thresholds for ethanol and tetralone were not

light, casual, and regular ethanol

Taste detection thresholds for ethanol and tetralone using a forced-choice, staircase

To evaluate taste quality for ethanol near th and irritancy thresholds for ethanol within individuals to assess their relative ranking.

To evaluate the effects of rinses with ethanol prior to taste compound sampling.

procedure. Quality ratings (\% sweet, $\%$

salty, \% sour, and \% bitter) of ethanol and tetralone were obtained for new samples at threshold and for each of the two concentration steps above each subjects' threshold concentration. Intensity udgements of suprathreshold concentrations of ethanol and tetralone were obtained by having participants ra concentrations of each in duplicate on 100-cm VAS.
Participants recruited by public

advertisement, divided in 17 light bee consumers, 17 casual beer consumers, and 16 regular consumers.

Oronasal olfactory detection thresholds for ethanol and trigeminal thresholds in the nasal cavity were performed;

anthropometric measurements and diet anthropometric measurem
50 healthy participants (25 females, 25 males; mean age $=28.0$ years; mean $\mathrm{BMI}=23.6 \mathrm{~kg} / \mathrm{m}^{2}$
At the first visit, salty taste acuity and preference were measured by sensory evaluation, and dietary intake data were collected using a 24-h recall method.

Salty taste acuity determined by measuring the salty taste recognition threshold with 15 sodium chloride test solutions, administered from lowest to highest concentration, and viceversa. Salty taste preference by measuring the Salty taste preference by measuring the preferred concentration of sodium chloride (with a salt-meter) in a clear soup made with soybean sprouts, seasoned with salt until suiting individual taste.

polymorphism, zin salty taste perception includ salty taste acuity and
At the second visit, fasting blood samples and anthropometric data were obtained. Additionally, subjects submitted the

dietary intake records at the second visit.

Three-day dietary record, anthropometric measurements, biochemical assessments, and $\alpha \mathrm{ENaC}$ A663T genotyping were collected.
To evaluate the relationship between the dietary intake of zinc and zinc sulfate taste acuity.
Bryce-Smith and Simpson zinc taste test: Participants were instructed to taste but not swallow $10 \mathrm{~mL}$ of a $0.1 \%$ zinc sulfate solution and then spit the solution into a sink.

consumers. The variance in ethanol and tetralone taste threshold was about twice as high in light users compared to heavier users. Suprathreshold intensity ratings of ethanol and tetralone did not differ

between ethanol user groups. Rinse with nonalcoholic beer led to higher sweetness intensity $(p=0.006)$ compared with other conditions, and higher saltiness and sourness ratings when compared with carbonated water $(p=0.023$ and $p=0.016$ carbonated water $(p=0.023$ and $p$
for $0.5 \%$ and $1.5 \% \mathrm{NaCl}$ solutions, respectively) and beer ( $p<0.001$ for both).

The salty taste threshold was positively correlated with the sodium intake $(r=0.18, p<0.01)$. In women, salty taste threshold was significantly lower in the third tertile of total zinc intake and available zinc intake than in the first tertile $(p=0.04$ and $p=0.02)$. Negative

207 healthy participant (104 males, mean age $=23$ mean $\mathrm{BMI}=23.0 \mathrm{~kg} / \mathrm{m}^{2}$;

103 females, mean age $=$ correlation between available zinc intake and salty taste threshold in women $(r=-0.21, p=0.04)$, especially with $\alpha \mathrm{ENaC}$ A663T AA genotype. In men, alty taste thresholds were similar in all tertiles of available zinc intake.

Female zinc intake was not correlated with zinc sulfate taste perception as gauged by both the zinc taste test

363 healthy participants (286 females, mean age $=21.0$ years; 77 males, mean age $=20.6$ years) $(\mathrm{r}=0.014, p=0.816)$ and the taste intensity visual analog scale $(r=0.025, p=0.679)$. Male zinc intake was not correlated with zinc taste test scores $(r=0.199, p=0.099)$ but significantly correlated with taste intensity VAS $(\mathrm{r}=0.237 ; p=0.048)$. questionnaire calculating zinc intake

intake of foods containing zinc. marking a line perpendicular to a continuous horizontal line measuring $100 \mathrm{~mm}$ at a point that reflected their perceived intensity of the zinc sulfate solution. 
Table 2. Cont.

\begin{tabular}{|c|c|c|c|c|c|}
\hline Main Objectives of the Study & Taste Tests & $\begin{array}{l}\text { Setting/Protocol and Other } \\
\text { Outcome Measures }\end{array}$ & Subjects & Taste Results & Reference \\
\hline $\begin{array}{l}\text { - To determine if } \\
\text { participants could rate the } \\
\text { intensity of varying } \\
\text { concentrations of linoleic } \\
\text { acid presented in the form } \\
\text { of edible taste strips } \\
\text { To determine associations } \\
\text { between fat taste } \\
\text { sensitivity and body } \\
\text { fatness, examining how } \\
\text { food and beverage intake } \\
\text { prior to testing influenced } \\
\text { fat taste sensitivity }\end{array}$ & $\begin{array}{l}\text { Participants, wearing nose clips, rated the } \\
\text { intensity of edible strips impregnated } \\
\text { with either no stimulus (blank) or varying } \\
\text { concentrations of linoleic acid on a } 100 \\
\text { mm (VAS). The sucralose stimulus served } \\
\text { to check that participants could perform } \\
\text { the rating task using the VAS scale. }\end{array}$ & $\begin{array}{l}\text { A subset of adults recorded the amount of } \\
\text { food and beverage consumed during } \\
\text { their last eating occasion prior to testing. } \\
\text { One undergraduate dietetics student } \\
\text { entered the data into Nutritionist Pro } 5.0 \\
\text { dietary analysis software to eliminate } \\
\text { inter-rater error. } \\
\text { Intensity ratings of an edible taste strip } \\
\text { containing sucralose (to check that } \\
\text { participants could perform the rating task } \\
\text { using the VAS scale), a spicy cinnamon } \\
\text { candy (to evaluate trigeminal } \\
\text { nerve/chemesthetic sensitivity) and the } \\
\text { odor of spearmint extract (to confirm } \\
\text { functional olfactory capability) } \\
\text { were performed. } \\
\text { Anthropometric measurements } \\
\text { were collected. }\end{array}$ & $\begin{array}{l}735 \text { ( } 549 \text { adults, } 180 \text { children, } \\
6 \text { unknown; } 37.9 \% \text { were male; } \\
85.9 \% \text { White, } 3.1 \% \text { Asian, } \\
1.4 \% \text { Black and } 8.8 \% \\
\text { Hispanic; mean age } 33 \text {; mean } \\
\text { body fat percentage among } \\
\text { adults } 26.9 \text { ) obese and } \\
\text { non-obese participants }\end{array}$ & $\begin{array}{l}\text { There were significant differences } \\
(p<0.001) \text { for intensity ratings of low, } \\
\text { medium, and high concentrations of fat } \\
\text { taste stimuli. Ratings increased in a } \\
\text { dose-dependent fashion. There were } \\
\text { significant differences ( } p<0.001 \text { ) between } \\
\text { children's and adults' ratings of fat taste } \\
\text { intensity on a VAS scale. No differences } \\
\text { in fat taste intensity ratings were noted } \\
\text { between nonobese (236) and obese adults } \\
\text { (304), except for the medium linoleic acid } \\
\text { concentration where lean participants } \\
\text { rated the taste strip as more intense } \\
(p=0.03) \text {. Obese and nonobese women } \\
\text { were also more sensitive than } \\
\text { obese/nonobese men ( } p<0.001) \text { at the } \\
\text { highest concentration. In the obese } \\
\text { participants, for the medium } \\
\text { concentration, mono- and } \\
\text { polyunsaturated fat intake was negatively } \\
\text { associated with fat taste intensity ratings } \\
(\mathrm{r}=-0.21, p=0.021 ; \mathrm{r}=-0.24, p=0.006, \\
\text { respectively). }\end{array}$ & $\begin{array}{l}\text { Tucker RM } \\
\text { et al., } 2015 \\
\text { [22] }\end{array}$ \\
\hline $\begin{array}{l}\text { To assess the associations } \\
\text { between fat taste thresholds, } \\
\text { anthropometric measurements, } \\
\text { fat intake, and liking of } \\
\text { fatty foods }\end{array}$ & $\begin{array}{l}\text { All participants, wearing nose clips, were } \\
\text { tested for detection thresholds to oleic } \\
\text { acid (fat taste thresholds) and sensitivities } \\
\text { to the five basic tastes (sweet, salty, sour, } \\
\text { bitter, and umami). Fatty acid ascending } \\
\text { series mixed with long-life fat-free milk } \\
\text { by 3-Alternate Forced Choice } \\
\text { methodology were used for the fat taste } \\
\text { threshold measurement. Ascending } \\
\text { concentrations of sucrose, NaCl, citric } \\
\text { acid, caffeine and MSG were used for the } \\
\text { sensory evaluation of the five basic tastes. }\end{array}$ & $\begin{array}{l}\text { A 24-h dietary recall was used to assess } \\
\text { short-term dietary intake (energy intake, } \\
\text { total consumption of protein, total fat and } \\
\text { saturated, monounsaturated and } \\
\text { polyunsaturated fat, carbohydrates, } \\
\text { alcohol, and percentage of energy derived } \\
\text { from protein, fats, and carbohydrates) } \\
\text { using computer software FoodWorks. } \\
\text { To evaluate the participants' ability to } \\
\text { discriminate different levels of fat content } \\
\text { between food samples, the fat raking task } \\
\text { was evaluated. } \\
\text { Anthropometric measurements } \\
\text { were collected. }\end{array}$ & $\begin{array}{l}69 \text { Australian females (mean } \\
\text { age 41.3; mean BMI 26.3) in } \\
\text { under- (3), normal- (33), } \\
\text { over-weight (13) or obese } \\
\text { (20) individuals }\end{array}$ & $\begin{array}{l}\text { Fat taste sensitivity appears to be } \\
\text { associated with short-term fat intake, but } \\
\text { not body size in this group of females. } \\
\text { There was no association between fat } \\
\text { taste rank and total dietary fat intake, } \\
\text { with or without controlling for energy. } \\
\text { This indicates that fat taste sensitivity is } \\
\text { associated with the proportion of fat } \\
\text { consumed relative to total energy intake } \\
\text { rather than the total amount of fat } \\
\text { consumed. No significant associations } \\
\text { were observed between fat taste rank and } \\
\text { sensitivity to any of the five basic tastes } \\
\text { (sweet, salty, sour, bitter, and umami). }\end{array}$ & $\begin{array}{l}\text { Costanzo A } \\
\text { et al., } 2017 \\
{[42]}\end{array}$ \\
\hline
\end{tabular}

VAS: Visual analogue scale; BMI: Body Mass Index; NaCl: sodium chloride; MSG: monosodium glutamate. $p$ : $p$-value; in grey background: studies also involving patients. 
Table 3. Interventional studies included in the review.

\begin{tabular}{|c|c|c|c|c|c|}
\hline Main Objectives of the Study & Taste Tests & $\begin{array}{l}\text { Setting/Protocol and Other } \\
\text { Outcome Measures }\end{array}$ & Subjects & Taste Results & Reference \\
\hline $\begin{array}{l}\text { To test if different sweetened } \\
\text { beverages may differently impact } \\
\text { on taste testing, OGTT, and } \\
\text { neuroimaging findings }\end{array}$ & $\begin{array}{l}\text { Before and after the } 2 \text {-weeks exposure } \\
\text { session, participants rated the perceptual } \\
\text { qualities of basic tastes (sucrose, } 0.56 \mathrm{M} \text {; } \\
\text { citric acid, } 18 \mathrm{mM} \text {; } \mathrm{NaCl}, 0.32 \mathrm{M} \text {; quinine, } \\
0.18 \mathrm{mM} \text {, and } \mathrm{MPG}(100 \mathrm{mM} \text { ) alone and } \\
\text { when combined as binary taste mixtures } \\
\text { (sucrose-citric acid, sucrose-quinine, } \\
\text { sucrose-MPG, citric acid-NaCl and } \\
\text { NaCl-quinine). Participants rated the } \\
\text { sweetness, sourness, saltiness, bitterness, } \\
\text { and umami intensity of each taste using } \\
\text { the gLMS. Sweet concentration preference } \\
\text { using a sucrose preference test pre- and } \\
\text { post-beverage exposure was used. Sweet, } \\
\text { sour, salty, umami, and tasteless/odorless } \\
\text { stimuli were presented with a } \\
\text { custom-designed gustometer in a block } \\
\text { design across two fMRI runs. }\end{array}$ & $\begin{array}{l}\text { All groups subjects were randomly } \\
\text { assigned to consume for } 2 \text { weeks: } \\
\text { (1) beverages sweetened with } 0.06 \mathrm{~g} \\
\text { sucralose (sweet uncoupled from } \\
\text { calories-LCS), (2) beverages sweetened } \\
\text { with } 30.38 \text { g sucrose (sweet coupled with } \\
\text { calories-Sugar), or (3) beverages } \\
\text { sweetened with sucralose and combined } \\
\text { with } 31.8 \mathrm{~g} \text { maltodextrin (Combo). } \\
\text { GLP-1, insulin, OGTT before and after the } \\
\text { exposure session, and anthropometric } \\
\text { measurements were recorded. }\end{array}$ & $\begin{array}{l}\text { Tirthy-nine healthy young } \\
\text { adults }(21 \text { females, } 18 \text { males; } \\
\text { mean age }=27.8 \text { years; mean } \\
\text { BMI }=23.7 \mathrm{~kg} / \mathrm{m}^{2} \text { ) }\end{array}$ & $\begin{array}{l}\text { Regressing insulin iAUC difference scores } \\
\text { on the BOLD-difference maps for sweet } \\
\text { taste showed a strong negative relation in } \\
\text { several limbic and mesolimbic areas in } \\
\text { the Combo group. In this group, the left } \\
\text { anterior insula, right middle insula, } \\
\text { anterior cingulate, right ventral tegmental } \\
\text { area, right putamen, and several cortical } \\
\text { areas in the superior temporal gyrus and } \\
\text { postcentral gyrus showed a decreased } \\
\text { fMRI-BOLD response to sweet taste as a } \\
\text { function of iAUC. In a second experiment } \\
\text { with maltodextrin consumption alone no } \\
\text { insulin sensitivity alteration was seen. }\end{array}$ & $\begin{array}{l}\text { Dalenberg } \\
\text { JR et al., } \\
2020 \\
\text { [43] }\end{array}$ \\
\hline $\begin{array}{l}\text { To investigate the immediate } \\
\text { effects of coffee consumption on } \\
\text { gustatory and olfactory } \\
\text { sensitivity on cohorts of } \\
\text { participants reguarly consuming } \\
\text { Cofee or Decaffeinated Coffee }\end{array}$ & $\begin{array}{l}\text { Taste-drop-test applied to assess the } \\
\text { recognition and detection threshold, } \\
\text { consisting of } 10 \text { steps of tastant dilutions } \\
\text { for sweet (sucrose), sour (citric acid), salty } \\
\text { (NaCl), and bitter (quinine) in tap water } \\
\text { solvent, with a halving of tastant } \\
\text { concentration in every dilution step. }\end{array}$ & $\begin{array}{l}15 \text { min after taste and smell testing, } \\
\text { participants were served a lukewarm } \\
\text { espresso and instructed to drink it in two } \\
\text { sips and to ensure that the coffee was } \\
\text { swirled around the entire oral cavity. } \\
\text { Within } 2 \text { min, participants were provided } \\
\text { with } 150 \mathrm{~mL} \text { of tap water and instructed } \\
\text { to swirl each sip and drink all of the } \\
\text { water. This was done to cleanse their } \\
\text { palates prior to retesting smell and taste } \\
\text { sensitivity, which took approximately } \\
20 \text { min. } \\
\text { Sniffin' Sticks Test (only in Regular Coffee } \\
\text { Group) was performed } \\
\text { Same procedure in a group using } \\
\text { de-caffeinated coffee }\end{array}$ & $\begin{array}{l}\text { Regular Coffee Group: } \\
101 \text { healthy participants } \\
\text { ( } 55 \text { females, } 46 \text { males; mean } \\
\text { age = } 25.5 \text { years). } \\
\text { Decaffeinated Coffee Group: } \\
55 \text { healthy participants } \\
\text { ( } 30 \text { females, } 25 \text { males; mean } \\
\text { age }=24.5 \text { years). }\end{array}$ & $\begin{array}{l}\text { Two minutes after coffee consumption, } \\
\text { the detection threshold for the sweet } \\
\text { tastant was increased (MD }=0.26, \\
p<0.001 \text { and } \mathrm{MD}=0.73, p<0.001) \text { while } \\
\text { the threshold for the bitter tastant was } \\
\text { significantly decreased (MD }=-0.56, \\
p<0.001 \text { and } \mathrm{MD}=-0.64, p<0.001) \text { in } \\
\text { Regular Coffee and Decaffeinated Coffee } \\
\text { Group, respectively. } \\
\text { The decrease in bitter sensitivity } \\
\text { (F(1,99) }=4.7975, p=0.031) \text { was found to } \\
\text { be larger in participants that did not } \\
\text { consume coffee daily }(\mathrm{n}=25 ; \text { decrease in } \\
\text { mean bitter sensitivity score of }-1.0) \text {. A } \\
\text { small negative correlation between } \\
\text { baseline tastant sensitivity and coffee } \\
\text { consumption for all tastants was found: } \\
\text { sweet }(\varrho=-0.17, p=0.09) ; \text { bitter } \\
(\varrho=-0.20, p=0.04) ; \text { salty }(\varrho=-0.08, \\
p=0.42) ; \text { sour }(\varrho=-0.07, p=0.50)\end{array}$ & $\begin{array}{l}\text { Fjaeldstad } \\
\text { AW and } \\
\text { Fernandes } \\
\text { HM, } 2020 \\
\\
{[44]}\end{array}$ \\
\hline
\end{tabular}


Table 3. Cont.

\begin{tabular}{|c|c|c|c|c|c|}
\hline Main Objectives of the Study & Taste Tests & $\begin{array}{l}\text { Setting/Protocol and Other } \\
\text { Outcome Measures }\end{array}$ & Subjects & Taste Results & Reference \\
\hline $\begin{array}{l}\text { To investigate the influence of a } \\
\text { habitual exposure to umami taste } \\
\text { on umami taste perception, } \\
\text { hedonics, and satiety }\end{array}$ & $\begin{array}{l}\text { Whole mouth suprathreshold taste } \\
\text { intensity ratings for aqueous umami, } \\
\text { sweet, and salty stimuli were captured on } \\
\text { the gLMS. Aqueous taste stimuli were } \\
\text { prepared in deionized water and were } \\
\text { presented twice, separately, in a series of } \\
\text { three ascending concentrations: sucrose } \\
\text { for sweet taste at } 27.0,81.0 \text {, and } \\
243.0 \mathrm{mmol} / \mathrm{L} \text {; sodium chloride }(\mathrm{NaCl}) \\
\text { for salty taste at } 11.1,33.3 \text {, and } \\
100.0 \mathrm{mmol} / \mathrm{L} \text {; MSG for umami taste at } \\
3.0,9.0 \text {, and } 27.0 \mathrm{mmol} / \mathrm{L} \text {. }\end{array}$ & $\begin{array}{l}\text { 4-week intervention with one cup of } \\
\text { broth daily. The treatment group's low } \\
\text { glutamate vegetable broth ( } 237 \mathrm{~mL} \text { ) was } \\
\text { supplemented with } 3.8 \mathrm{~g} \text { MSG. The } \\
\text { control group's broth contained no added } \\
\text { MSG, but was sodium-matched with } \\
1.8 \mathrm{~g} \mathrm{NaCl} \text { to ensure both broths } \\
\text { contained the same amount of sodium. } \\
\text { Both broths contained } 15 \mathrm{kcal}, 0.3 \mathrm{~g} \text { fat, } \\
2 \mathrm{~g} \text { carbohydrates, } 1 \mathrm{~g} \text { protein, and } \\
615 \mathrm{mg} \text { sodium. } \\
\text { Diet History Questionnaire, } \\
\text { anthropometric measurements, Leeds } \\
\text { Food Preference Questionnaire, } \\
\text { preference of real foods (using an hedonic } \\
\text { ratings after consuming samples of } \\
\text { different real foods) and an ad-libitum } \\
\text { test meal used to assess satiation and } \\
\text { satiety (using a VAS before and after both } \\
\text { savory and sweet course) were captured } \\
\text { at baseline and post-treatment } 4 \text {-week } \\
\text { intervention of testing sessions. }\end{array}$ & $\begin{array}{l}58 \text { healthy participants, } 30 \text { in } \\
\text { control and } 28 \text { in treatment } \\
\text { group }(72.4 \% \text { females; mean } \\
\text { age }=22.7 \text { years; mean } \\
\left.\mathrm{BMI}=21.8 \mathrm{~kg} / \mathrm{m}^{2}\right) .\end{array}$ & $\begin{array}{l}\text { At the start of the intervention, the broth } \\
\text { supplemented with MSG tended to be } \\
\text { rated as more intensely umami on } \\
\text { average compared to the control broth } \\
\text { (control: } 20.2 \pm 2.5 \text {; treatment: } 27.7 \pm 3.2) \text {, } \\
\text { although not significantly ( } p=0.06) \text {. } \\
\text { Treatment group for the highest aqueous } \\
\text { stimuli concentration of umami rated the } \\
\text { high concentration } 5.6 \text { units lower than } \\
\text { the baseline. Females in the treatment } \\
\text { group but not in control group rated the } \\
\text { umami stimulus } 8.4 \text { units lower on the } \\
\text { gLMS following exposure to MSG. } \\
\text { After } 4 \text { weeks, the control group } \\
\text { increased in consumption of savory foods } \\
\text { relative to baseline ( } 42 \text { g), while the } \\
\text { treatment group decreased intake ( }-36 \mathrm{~g} \text { ). } \\
\text { Desire for savory foods decreased in the } \\
\text { treatment group after } 4 \text { weeks }\end{array}$ & $\begin{array}{l}\text { Noel CA } \\
\text { et al., } 2018 \\
{[45]}\end{array}$ \\
\hline $\begin{array}{l}\text { To test how short-term fasted and } \\
\text { satiated states impact on } \\
\text { taste thresholds }\end{array}$ & $\begin{array}{l}\text { Determination of taste thresholds carried } \\
\text { out in blind conditions, using a series of } \\
\text { six pure chemicals in solution in a } \\
\text { commercialized drinking water with a } \\
\text { staircase-method and presented in a } \\
\text { random order with ascending } \\
\text { concentrations and up-and-down } \\
\text { procedure. Twofold step series ( } 0.3 \\
\text { log-step) included sucrose }(2.0 \text { to } \\
1000 \mathrm{mM}) \text {, fructose ( } 2.0 \text { to } 1000 \mathrm{mM}) \text {, } \\
\text { quinine sulphate }(0.0004 \text { to } 1.6 \mathrm{mM}) \text {, and } \\
\text { purified liquorice }(0.015 \text { to } 1 \mathrm{~g} / 1 \mathrm{lof} \\
\text { glycyrrhizin), whereas the solutions of } \\
\text { NaCl ( } 1.77 \text { to } 1000 \mathrm{mM}) \text { and PROP }(0.001 \\
\text { to } 3.2 \mathrm{mM}) \text { were diluted with a } 0.25 \\
\text { log-step. }\end{array}$ & $\begin{array}{l}\text { Participants were divided in two groups: } \\
\text { one group was tested first in the fasted } \\
\text { state, whereas the other one was first } \\
\text { tested in the satiated state. Both groups } \\
\text { were tested twice, within a 2-day interval: } \\
\text { in the morning between } 8: 30 \text { and } 10 \text { am, } \\
\text { in the fasted state (after an overnight fast), } \\
\text { and in the afternoon, about } 1 \text { h after a } \\
\text { standard lunch, completed before the test, } \\
\text { by ad libitum consumption of a standard } \\
\text { dish of sweetened cream. } \\
\text { Subjective hunger magnitude was } \\
\text { recorded on a nine points scale. }\end{array}$ & $\begin{array}{l}24 \text { participants }(21 \text { females, } \\
3 \text { males; mean age }=26 \text { years; } \\
\mathrm{BMI}<25 \mathrm{~kg} / \mathrm{m}^{2} \text { ) }\end{array}$ & $\begin{array}{l}\text { No statistically significant variation for } \\
\text { recognition threshold of both sugars } \\
\text { (sucrose and fructose), purified liquorice, } \\
\text { NaCl, PROP, or quinine sulphate when } \\
\text { comparing satiated and fasted states. } \\
\text { The mean level of subjective hunger } \\
\text { differed significantly between the fasted } \\
\text { and satiated states (respectively } 5.4 \pm 2.2 \\
\text { and } 1.8 \pm 0.9 ; p<0.0001 \text { ). }\end{array}$ & $\begin{array}{l}\text { Pasquet P } \\
\text { et al., } 2006 \\
\text { [46] }\end{array}$ \\
\hline
\end{tabular}


Table 3. Cont.

Main Objectives of the Study

Taste Tests
Setting/Protocol and Other Outcome Measures
Subjects

Taste Results

Sweet taste intensity rating by marking

117-mm printed gLMS and pleasantnes

rating on a 23-point category scale for

vanilla puddings and raspberry

beverages varied in amounts of added

sucrose: $0 \%, 6.6 \%, 11 \%, 25 \%, 31 \%, 40 \%$,

$47 \%$, and $52 \%$ by weight and $0 \%, 2.5 \%$,

$5 \%, 7.5 \%, 10 \%, 12.5 \%, 16 \%, 19 \%$, and $25 \% \quad$ After 1 month of normal diet, the control by weight, respectively.

roup was instructed to maintain their

intake of simple sugars for the first

Pleasantness rating on a 23-point category scale for broth and soda crackers varied group was instructed to lower their suga $01.0,0.16,0.25,0.39,0.62,0.87,0 \%$, intake by $40 \%$ (relative to month 1 ) $01.0,0.16,0.25,0.39,0.62$, and $0.87 \mathrm{~mol} / \mathrm{L}$ during months $2-4$. Both groups were
and $0.5 \%, 1.2 \%, 2.5 \%, 4.5 \%$, and $8.5 \%$ by allowed to follow any diet they wished weight, respectively. Sensory testing occurred for all concentrations of all stimuli.

Sucrose detection thresholds by a forced-choice ascending method of limits. In each trial, subjects sampled a $10-\mathrm{mL}$

aliquot of sucrose solution and two 10-mL aliquot of sucrose solution and two 10-m

amounts ranged from 0.0006 to

$0.06 \mathrm{~mol} / \mathrm{L}$ in 121.52 -fold

concentration steps.

Taste tests were performed each mon food/activity re
4 months of the study. The low-sugar two groups in rated sweetness intensity during month 1 and 2. By month 3, the low sugar group rated low-concentration samples as sweeter than did the control group (more for pudding than for beverage samples). By month 4 , the row-sugar group gave higher sw group (mean age $=34.4 \pm 9.7$ years; female $=56.3 \%$ ) and

allowed to follow any distipants in low-sugar during the last (fifth) diet group (mean age $=36.7 \pm 10.2$ years; female $=53.4 \%$ )

added-sugar concentrations. Durin month 5, the differences between group were no longer apparent. In contrast to sweet intensity, there were no significan differences between groups for rated pleasantness. The low-sugar group gave significantly han they did during month $1(p<0.02)$. No effect on broth and cracker samples.
No significant differences between the low-sugar group gave higher sweetness
Wise PM et al., 2015 
Table 3. Cont.

\section{Main Objectives of the Study}

\section{Taste Tests}

Recognition thresholds were measured for sweet, salty, and bitter qualities of taste using different concentrations of sucrose (from 1.9 to $233.6 \mathrm{mmol} / \mathrm{L}$ ), salt (from 1.3 to $171.2 \mathrm{mmol} / \mathrm{L}$ ), and quinin (from 0.077 to $7.860 \mathrm{mmol} / \mathrm{L}$ ) solutions respectively, in cups of $5 \mathrm{~mL}$ of distilled

To assess the effects of short-term caloric deprivation and satiety on recognition taste thresholds

technique and the standard

two-alternative forced-choice technique. Eight concentrations of each substance under test were presented in rand under ter were presented in randomiz order. The lowest intensity of a taste timulus, which could be recognised by taste, was noted as the threshol of recognition.

CKD patients and healthy volunteers tasted different concentrations of

To analyze the gustatory threshold for salty taste in CKD patients

To investigate the effect of short-term salt restriction on the gustatory threshold and after 1 week of protocol study. The sodium-impregnated test strips before impregnated salt concentration was initially $0 \%$ and increased in $0.2 \%$ intervals from 0.6 to $1.6 \%$. Detection and recognition threshold were assessed.

\section{Setting/Protocol and Other} Outcome Measures

Taste Results

Participants took their last meal between $6 \mathrm{pm}$ and $7 \mathrm{pm}$, they missed a breakfast the following morning, and had a lunch at $12.30 \mathrm{pm}$. All volunteers had the same food at dinner and lunch. Taste

thresholds in hunger state in all subjects were measured between 9 am and $10 \mathrm{am}$ after 14-16 h of fasting. A 1-h interval

was allowed between food intake and

measurements of taste thresholds in order to avoid the lingering effects of taste adaptation. In eight volunteers, taste thresholds were initially detected in satiated state after a standard dinner and then in hunger state the following morning. In the remaining eight subjects, the order of testing was the opposite:

Taste thresholds were initially detected in the morning in hunger state and then in satiated state after a standard lunch.

Subjective magnitude of hunger was used to assess at the beginning of the testing procedure on the basis of a self-reported five-points scale.

One week of sodium restriction by mean of an educational program including a meal with low salt ( $5 \mathrm{~g} /$ day), low protein $(0.8 \mathrm{~g} / \mathrm{kg} /$ day $\times$ ideal body weight $)$ and to all CKD patients. The calories werenot

16 male participan

$\mathrm{BMI}=20.5-25 \mathrm{~kg} / \mathrm{m}^{2}$

thresholds for the sweet and salty substances were significantly higher during satiety state than in fasting state $(p<0.05$ and $p<0.02$, respectively). The mean value of recognition thresholds for the bitter substance in fasting states and that after caloric loading did not differ significantly. The difference in taste sur thresholds between two subgroups of subjects divided on the basis of order of tasting was not statistically significant.
Group A: 29 patients with chronic kidney disease 19 males and 10 females; no smoking. 10 with diabetic nephrop

11 healthy volunteers (mean age $=37.7$ years; 8 males an 3 females; no smoking and 3 females; no smoking and
no diabetic nephropathy)
After 1 week of sodium restriction, the average value of the recognition

from $0.84 \pm 0.27$ to $0.76 \pm 0.25 \%(p<0.05) \quad$ Kusaba T and from $0.68 \pm 0.14$ to $0.65 \pm 0.09 \%$ in value of the detection threshold in CKD patients also decreased from $0.74 \pm 0.21$ to $0.71 \pm 0.23 \%$ (NS) and from $0.64 \pm 0.08$ (0.8 $\mathrm{g} / \mathrm{kg} / \mathrm{day} \times$ ideal body weight) and ( had diabetes mellitus. healthy volunteer (NS). The average to $0.62 \pm 0.06$ in healthy volunteers (NS). 
Table 3. Cont

\begin{tabular}{|c|c|c|c|c|c|}
\hline Main Objectives of the Study & Taste Tests & $\begin{array}{c}\text { Setting/Protocol and Other } \\
\text { Outcome Measures }\end{array}$ & Subjects & Taste Results & Reference \\
\hline $\begin{array}{l}\text { To investigate changes in } \\
\text { the sweet taste threshold } \\
\text { and leptin serum levels } \\
\text { during a } \\
\text { weight-loss program. } \\
\text { To determine if the leptin } \\
\text { receptor polymorphism } \\
\text { (Lys109Arg) affects the } \\
\text { taste change. }\end{array}$ & $\begin{array}{l}\text { Subjects tasted } 10 \text { different concentrations } \\
\text { of sucrose dissolved in sterile water } \\
(0.0098,0.0195,0.0391,0.0781,0.1560, \\
0.3130,0.6250,1.2500,2.5000 \text { and } 5.0000 \%) \\
\text { according to the whole-mouth gustatory } \\
\text { method, before and after } 12 \text { weeks } \\
\text { protocol study. } \\
\text { Detection threshold was measured. }\end{array}$ & $\begin{array}{l}\text { Participants completed a 12-week } \\
\text { weight-loss program based on energy } \\
\text { restriction through diet and exercise, } \\
\text { which aimed at achieving their } \\
\text { optimal weight. } \\
\text { Changes in serum leptin levels were } \\
\text { evaluated during a loss-weight program } \\
\text { in connection with a leptin receptor } \\
\text { polymorphism (Lys109Arg) that may be } \\
\text { related to insulin and } \\
\text { glucose metabolism. }\end{array}$ & $\begin{array}{l}20 \text { obese, but otherwise } \\
\text { healthy, free-living Japanese } \\
\text { females (mean } \\
\text { age }=55 \pm 7 \text { years; mean } \\
\text { weight }=61.7 \pm 4.6 \mathrm{Kg} \text {; mean } \\
\text { BMI }=26.1 \pm 1.7 \mathrm{~kg} / \mathrm{m}^{2} \text { ) }\end{array}$ & $\begin{array}{l}\text { The sweet taste threshold decreased } \\
\text { significatively in a solution of sucrose } \\
(p=0.004) \text {; in contrast, there was no } \\
\text { difference in changes to the sweet taste } \\
\text { threshold between the groups with } \\
\text { versus without the Lys109 allele. Serum } \\
\text { leptin levels decreased significantly } \\
(p=0.014) \text { and were significatively } \\
\text { correlated with those in the sweet taste } \\
\text { threshold, independently from the initial } \\
\text { threshold levels and the Lys109 allele. }\end{array}$ & $\begin{array}{l}\text { Umabiki M } \\
\text { et al., } 2010 \\
\text { [50] }\end{array}$ \\
\hline $\begin{array}{l}\text { To evaluate the effects of a } \\
\text { high-fat and low-fat diet on taste } \\
\text { sensitivity to oleic acid. }\end{array}$ & $\begin{array}{l}\text { Taste thresholds were established } 24 \mathrm{~h} \\
\text { before initiating a prescribed diet, and } \\
\text { again during week } 4 \text { of each dietary } \\
\text { intervention. Oral sensitivity to C18:1 } \\
\text { was determined using a fatty acid } \\
\text { ascending series }(0.02,0.06,1,1.4,2,2.8 \text {, } \\
3.8,5,6.4,8,9.8 \text {, and } 12 \mathrm{mM}) \text { mixed with } \\
\text { long-life non-fat milk by a 3-Alternate } \\
\text { Forced Choice methodology }\end{array}$ & $\begin{array}{l}\text { All participants were randomized into } \\
\text { two groups, which would consume, over } \\
\text { a } 4 \text {-week period, modified fat diets in the } \\
\text { following orders: Group } 1 \text { : high-fat } \\
\text { ( }>45 \% \text { fat) diet followed by low-fat } \\
\text { ( }<20 \% \text { fat) diet. Group } 2 \text { : low-fat } \\
\text { ( }<20 \% \text { fat) diet followed by high-fat } \\
\text { ( }>45 \% \text { fat) diet. There was a compulsory } \\
\text { 2-week wash-out period between } \\
\text { the diets. } \\
\text { Fat ranking task was assessed to test the } \\
\text { subjects' ability to discriminate between } \\
\text { custards containing small differences } \\
\text { ( } 2-4 \% \text { in their fat content and to establish } \\
\text { what effect consumption of a modified fat } \\
\text { diet may have on their ability to detect } \\
\text { these differences. } \\
\text { Subjects were required to rate their liking } \\
\text { and preference of five sets of RF and LF } \\
\text { foods by using a nine-point hedonic scale. }\end{array}$ & $\begin{array}{l}19 \text { lean }(\text { mean age }=33 \text { years; } \\
\left.\text { mean } \mathrm{BMI}=23.2 \mathrm{~kg} / \mathrm{m}^{2}\right) \text { and } \\
12 \text { overweight } / \text { obese }(\text { mean } \\
\text { age }=40 \text { years; mean } \\
\left.\mathrm{BMI}=28 \mathrm{~kg} / \mathrm{m}^{2}\right) \\
\text { unrestrained eater subjects }\end{array}$ & $\begin{array}{l}\text { Consumption of the low-fat diet } \\
\text { increased taste sensitivity to C18:1 among } \\
\text { lean and overweight/obese subjects } \\
\text { ( } p=0.05) \text { and increased the subjects' } \\
\text { ability to perceive small differences in the } \\
\text { fat content of custard ( }(p=0.05) \text {. } \\
\text { Consumption of the high-fat diet } \\
\text { significantly decreased taste sensitivity to } \\
\text { C18:1 among lean subjects }(p=0.05) \text {. }\end{array}$ & $\begin{array}{l}\text { Stewart JE } \\
\text { and Keast } \\
\text { RSJ, } 2011 \\
\text { [21] }\end{array}$ \\
\hline
\end{tabular}


Table 3. Cont

\begin{tabular}{|c|c|c|c|c|c|}
\hline Main Objectives of the Study & Taste Tests & $\begin{array}{l}\text { Setting/Protocol and Other } \\
\text { Outcome Measures }\end{array}$ & Subjects & Taste Results & Reference \\
\hline $\begin{array}{l}\text { To investigate whether } \\
\text { encapsulated sodium and } \\
\text { potassium supplementation lead } \\
\text { to altered salt taste responses }\end{array}$ & $\begin{array}{l}\text { Participants were subjected to sensory } \\
\text { evaluation in week } 0,5,9 \text {, and } 13 \text {. They } \\
\text { started with the detection threshold test } \\
\text { by 3-Alternate Forced Choice of } \mathrm{NaCl} \\
\text { ascending concentrations }(0.0125,0.025 \text {, } \\
0.05,0.1,0.2,0.4,0.8,1.6,3.2 \text { and } \\
6.4 \mathrm{~g} \mathrm{NaCl} / \mathrm{L}) \text {. After that, they rated } \\
\text { pleasantness and saltiness intensity of } \\
\text { different salt concentrations of water }(0 \text {, } \\
0.05,0.16 \text {, and } 0.5 \mathrm{M} \mathrm{NaCl}) \text {, tomato juice } \\
(0.03,0.05,0.09,0.16,0.28 \text {, and } 0.5 \mathrm{M} \\
\mathrm{NaCl}), \text { and bread }(0.5 \%, 1 \%, 2 \% \text {, and } \\
4 \% \mathrm{NaCl})\end{array}$ & $\begin{array}{l}\text { Participants were exposed to a fully } \\
\text { controlled low sodium and low } \\
\text { potassium diet (targeted to provide } 2 \mathrm{~g} \text { of } \\
\text { sodium and } 2 \mathrm{~g} \text { of potassium at an energy } \\
\text { intake of } 2500 \text { kcal a day) for } 13 \text { weeks. } \\
\text { Participants received capsules with } \\
\text { sodium ( } 3 \mathrm{~g} / \mathrm{d} \text { ), potassium ( } 3 \mathrm{~g} / \mathrm{d} \text { ) or } \\
\text { placebo, for } 4 \text { weeks each, in randomized } \\
\text { order in a double-blind crossover design. } \\
\text { To compare changes in taste responses } \\
\text { and desire-to-eat salty foods, five sweet } \\
\text { foods (pancake with sugar, gingerbread, } \\
\text { bananas, cookies, and chocolate), and } \\
\text { foods that were neither dominant in } \\
\text { sweet nor salty taste ('neutral' taste) } \\
\text { (boiled egg, cucumber, unsalted cashew } \\
\text { nuts, rice waffle, yoghurt) were included } \\
\text { by using a } 100 \text { mm VAS (visual analogue } \\
\text { scale). Participants were instructed to } \\
\text { collect } 24 \text {-h urine for the quantitative } \\
\text { determination of sodium and potassium. }\end{array}$ & $\begin{array}{l}26 \text { participants }(\text { mean } \\
\text { age }=66 \text { years; mean } \\
\mathrm{BMI}=26.8 \mathrm{~kg} / \mathrm{m}^{2} \text { ) with } \\
\text { untreated upper-range } \\
\text { prehypertension or stage } \\
1 \text { hypertension. }\end{array}$ & $\begin{array}{l}\text { The threshold was not affected over the } \\
\text { weeks during the intervention diet } \\
(p=0.75) \text {, not affected by } \\
\text { supplementation }(p=0.59) \text {, and there was } \\
\text { no interaction between duration and } \\
\text { supplementation }(p=0.43) \text {. }\end{array}$ & $\begin{array}{l}\text { Bolhuis DP } \\
\text { et al., } 2015 \\
\text { [51] }\end{array}$ \\
\hline $\begin{array}{l}\text { To assess the effect of a low-fat or } \\
\text { portion control diet on fat taste } \\
\text { thresholds, fat perception, } \\
\text { and preference }\end{array}$ & $\begin{array}{l}\text { All participants were required to attend } \\
\text { one laboratory session at baseline and } \\
\text { week } 6 \text {. They tasted a series of } 13 \text { variants } \\
\text { of the fatty acid vehicle (non-fat milk) } \\
\text { with increasing concentrations of } C 18: 1 \\
(0.02,0.06,1,1.4,2,2.8,3.8,5,6.4,8,9.8, \\
12 \text {, and } 20 \mathrm{mM} \text { ) to evaluate fat detection } \\
\text { threshold, and a series of eight different } \\
\text { concentrations of sucrose }(0.99,1.61,2.75 \text {, } \\
4.55,7.56,12.62,21.03,35.05) \text { and } \mathrm{NaCl} \\
(2.74,4.11,5.82,8.21,11.81,16.77,23.96, \\
\text { and } 34.22 \mathrm{mM} \text { ) to evaluate sweet and } \\
\text { salty detection thresholds by using } \\
\text { ascending forced choice triangle tests. }\end{array}$ & $\begin{array}{l}\text { Participants were randomized to follow } \\
\text { one of two weight loss diets: }(1) \\
\text { consumption of a low-fat }(<25 \% \text { total } \\
\text { energy from fat) diet }(n=26) \text { or }(2) \\
\text { consumption of a PC ( } 33 \% \text { total energy } \\
\text { from fat, reduction in total energy by } \\
25 \% \text { ) diet ( } n=27) \text {, for } 6 \text { weeks. } \\
\text { Anthropometric measurements were } \\
\text { recorded. In order to test the subjects' } \\
\text { ability to discriminate between custards } \\
\text { containing small differences ( } 2-4 \%) \text { in } \\
\text { their fat content, the fat ranking task was } \\
\text { evaluated. Participants completed a } \\
\text { preference test with three sets (9-point } \\
\text { hedonic scale) of RF and LF foods for the } \\
\text { hedonic evaluation. }\end{array}$ & $\begin{array}{l}53(17 \text { males and } 36 \text { females; } \\
\text { mean age }=56.5 \pm 1.9 \text { years; } \\
\text { mean } \\
\left.\mathrm{BMI}=32.3 \pm 0.7 \mathrm{~kg} / \mathrm{m}^{2}\right) \\
\text { overweight } / \text { obese subjects. }\end{array}$ & $\begin{array}{l}\text { Consumption of the LF and PC diets over } \\
\text { the } 6 \text {-week period significantly decreased } \\
\text { C18:1 threshold }(p=0.014) \text {, and the effect } \\
\text { tended to be stronger in the LF diet } \\
\text { versus PC diet }(p=0.060) \text {. Diets had no } \\
\text { significant effect on detection thresholds } \\
\text { for sucrose ( } p=0.227) \text { or } \mathrm{NaCl}(p=0.558) \text {. }\end{array}$ & $\begin{array}{l}\text { Newman LP } \\
\text { et al., } 2016 \\
{[52]}\end{array}$ \\
\hline
\end{tabular}


Table 3. Cont

\begin{tabular}{|c|c|c|c|c|c|}
\hline Main Objectives of the Study & Taste Tests & $\begin{array}{l}\text { Setting/Protocol and Other } \\
\text { Outcome Measures }\end{array}$ & Subjects & Taste Results & Reference \\
\hline $\begin{array}{l}\text { To determine the effect of a } \\
\text { high-fat meal immediately prior } \\
\text { to detection threshold testing for } \\
\text { oleic acid }\end{array}$ & $\begin{array}{l}\text { Fat taste thresholds to C18: } 1 \text { (added to } \\
\text { long-life skim milk samples at varying } \\
\text { concentrations }[0.02,0.06,1,1.4,2,2.8,3.8 \text {, } \\
5,6.4,8,9.8 \text {, and } 12 \mathrm{mM}] \text { ) was determined } \\
\text { using triangle tests with ascending forced } \\
\text { choice methodology } 1 \mathrm{~h} \text { and } 2 \mathrm{~h} \text { after the } \\
\text { frittatas administration. } \\
\text { Fat ranking task in which participants } \\
\text { were presented with custard samples } \\
\text { containing varying amounts of vegetable } \\
\text { oil }(0,2,6 \text { and } 10 \%) \text { and ranking the } \\
\text { fattiness of each sample. }\end{array}$ & $\begin{array}{l}\text { Frittatas contained varying amounts of } \\
\text { fat: high-fat frittata ( } 60 \% \text { fat: } 21 \% \\
\text { carbohydrate: } 18 \% \text { protein) contained a } \\
\text { total of } 9.7 \mathrm{~g} / 100 \mathrm{~g} \text { of fat and } 2.4 \mathrm{~g} \\
(2410 \mathrm{mg} \text { ) of } \mathrm{C} 18: 1 \text { per } 100 \mathrm{~g} \text {; the } \\
\text { balanced-fat frittata ( } 33 \% \text { fat: } 32 \% \\
\text { carbohydrate: } 32 \% \text { protein) contained a } \\
\text { total of } 3.0 \mathrm{~g} / 100 \mathrm{~g} \text { of fat and } 1.3 \mathrm{~g} \\
(1261 \mathrm{mg}) \mathrm{C} 18: 1 \mathrm{per} 100 \mathrm{~g} \text {; and the low-fat } \\
\text { frittata ( } 20 \% \text { fat: } 43 \% \text { carbohydrate: } 33 \% \\
\text { protein) contained a total of } 1.7 \mathrm{~g} \text { of fat } \\
\text { per serving and } 0.7 \mathrm{~g} \text { ( } 710 \mathrm{mg}) \mathrm{C} 18: 1 \mathrm{per} \\
100 \mathrm{~g} \text {. } \\
\text { Hedonic tests using a range of regular-fat } \\
\text { and low-fat foods including cream cheese, } \\
\text { vanilla yoghurt, and chocolate mousse } \\
\text { were used; food consumption record of } \\
\text { the day before their first testing session } \\
\text { was collected. }\end{array}$ & $\begin{array}{l}32 \text { participants }(15 \text { males: } \\
\text { mean age }=49.3 \text { years, mean } \\
\text { BMI }=24.7 \mathrm{~kg} / \mathrm{m}^{2} ; \\
17 \text { females: mean } \\
\text { age }=31.5 \text { years, mean } \\
\left.\text { BMI }=21.9 \mathrm{~kg} / \mathrm{m}^{2}\right) . \text { Out of } \\
\text { the total } 32 \mathrm{participants}, 7 \\
\text { were classified as } \\
\text { overweight } / \text { obese }(5 \text { males, } \\
2 \text { females, mean } \\
\left.\text { BMI }=29.1 \mathrm{~kg} / \mathrm{m}^{2}\right)\end{array}$ & $\begin{array}{l}\text { Fat taste threshold and fat ranking were } \\
\text { not different after the three different } \\
\text { fat-content breakfasts, as well as no } \\
\text { difference in food preferences } \\
\text { No significant difference in fatty acid } \\
\text { threshold between lean and } \\
\text { overweight/obese }\end{array}$ & $\begin{array}{l}\text { Newman LP } \\
\text { et al., } 2016 \\
\text { [53] }\end{array}$ \\
\hline
\end{tabular}

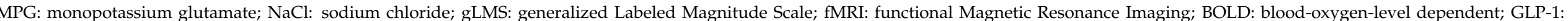

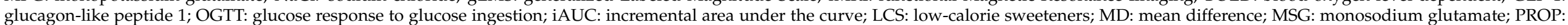

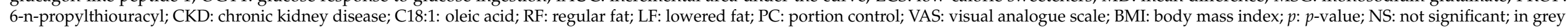
background: studies also involving patients. 


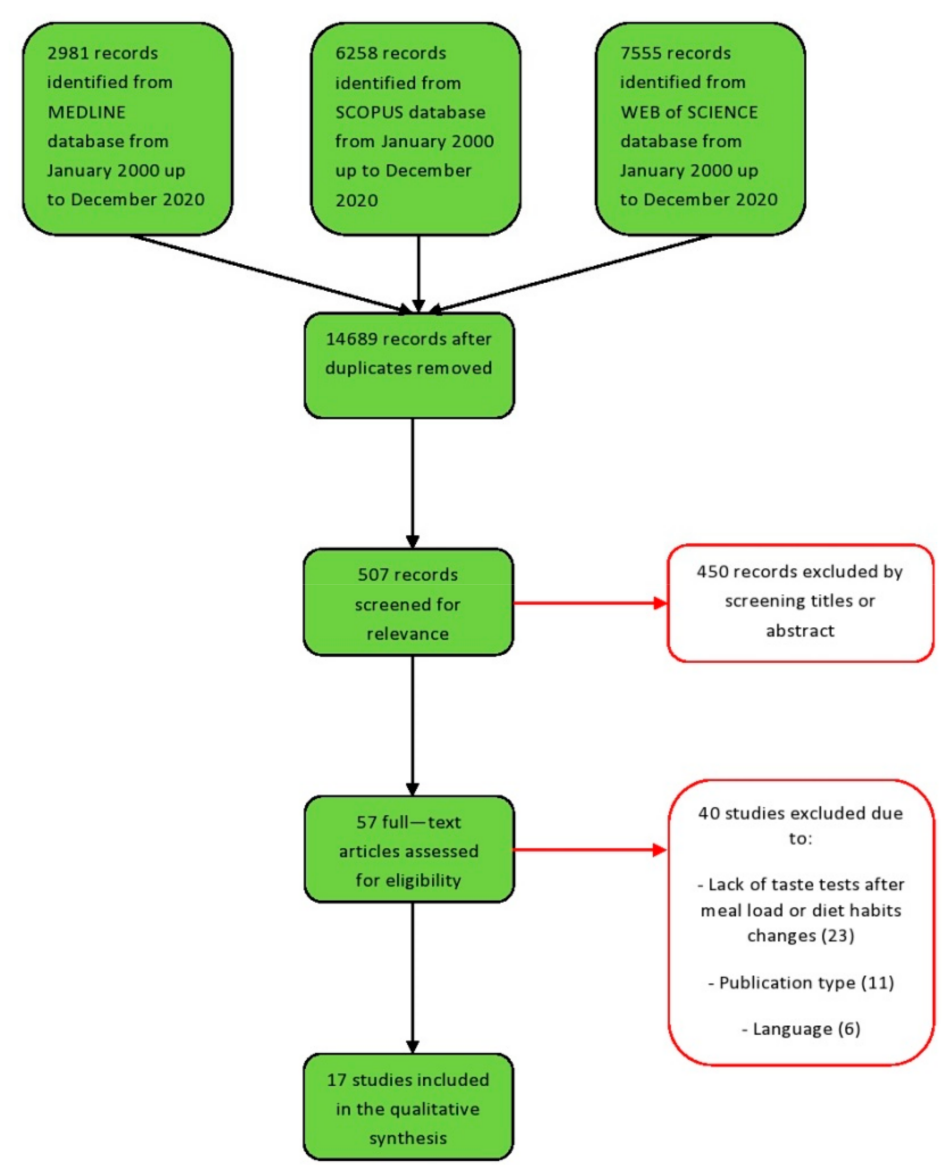

Figure 1. Selection process for the studies included in the scoping review. The Preferred Reporting Items for Systemic Reviews and Meta-Analyses for scoping reviews [PRISMA-sc (according to Tricco et al. [35])] flow diagram depicts the number of records identified, included, and excluded, and the reasons for exclusion, through the different phases of the scoping review.

\subsection{Observational Studies}

Five studies were conducted by implementing an observational approach to assess the effect of different nutrients found in free-living dietary habits on the perception of taste: three in healthy subjects [39-41] and two in patients [22,42]. The study of Mattes and DiMeglio performed on 50 usual healthy alcohol consumers [39] found that the variance in ethanol and tetralone taste threshold was around twice as high in light users as in heavier users, that a rinse with nonalcoholic beer led to a greater intensity of sweetness compared with other conditions, and higher saltiness and sourness ratings when compared with carbonated water. Bitterness ratings were lower after nonalcoholic beer compared to after carbonated water, and a rinse with beer induced lower bitterness ratings compared with other conditions [39].

Noh et al. stratified 207 healthy participants according to their sodium and zinc intake by means of a dietary intake record method and epithelium sodium channel $(\alpha \mathrm{ENaC})$ A663T gene polymorphism (associated with the risk of developing hypertension) [40]. The salty taste threshold was positively correlated with the sodium intake in the whole population but only in women it was significantly lower in the third tertile of total zinc intake and available zinc intake than in the first tertile. A negative correlation between the available zinc intake and salty taste threshold was found in $\alpha \mathrm{ENaC}$ A663T AA genotype women [40]. Following a similar protocol setting, in a study by Zdilla et al., 363 participants were enrolled, their daily zinc intake was evaluated, and they were tested for zinc taste acuity [41]. Female zinc intake was not correlated with the perception of the taste of 
zinc sulfate. Male zinc intake was not correlated with zinc taste test scores, but it was significantly correlated with the taste intensity visual analog scale. In 2015, Tucker et al. examined interactions between fat taste (linoleic acid) and dietary fat intake by enrolling 735 subjects, including obese and non-obese subjects [22]. Body fat was not correlated with fat intensity rating and no difference was found in fat intensity rating between obese and non-obese adults except for medium linoleic acid concentration rated higher by lean subjects. In the obese participants, for the medium concentration, mono- and poly-unsaturated fat intake was negatively associated with fat taste intensity ratings [22]. Similarly, 69 Australian females in normal or abnormal (underweight, overweight, or obese) weight conditions were tested by Costanzo et al. for detection thresholds to oleic acid and sensitivities to the five basic tastes (sweet, salty, sour, bitter, and umami) [42]. A 24-h dietary recall was used to assess subjects' short-term dietary intake. Fat taste sensitivity appeared to be associated with short-term fat intake with the proportion of fat consumed relative to total energy intake rather than the total amount of fat consumed. No significant associations were observed between fatty taste rank and sensitivity to any of the five basic tastes [42].

\subsection{Interventional Studies}

Twelve studies were performed by testing taste after an interventional approach (Table 3): 6 of which enrolled only healthy subjects [43-48] and 6 which also included patients affected by different disorders [21,49-53].

In order to reproduce food conditions that possibly lead to taste alterations, some studies were designed to administer a specific food stimulus over a defined period and retest taste sensitivity. Dalenberg et al. evaluated taste perception in 39 healthy young adults who consumed seven sucralose-sweetened beverages with, but not without a carbohydrate, over 2 weeks [43]. The taste perception was found unaltered while a decreased insulin sensitivity in the healthy participants receiving sucralose combined with maltodextrin was correlated with reductions in the midbrain, and insular and cingulate brain areas were correlated with blood oxygenation level dependent (BOLD)-responses to sweet, but not sour, salty or savory taste as assessed with fMRI. In another short-term study by Noel et al., investigating the impact of 4 weeks of broth administered daily with or without monosodium glutamate (MSG) on suprathreshold taste intensity ratings, liking preferences and ad-libitum test meal, the treatment group showed a marginal difference for the highest aqueous stimuli concentration of umami but not for sweet or salty tastes when compared with the control group and rated the high concentration 5.6 units lower than the baseline [45]. In a longer study (5 months), Wise et al. found that reducing sugar of about $40 \%$ in the routinary diet induced participants to rate by the third month low-concentration samples as sweeter than did the control group and to give higher sweetness ratings across a wide range of added-sugar concentrations [47]. Other authors further reduced the time length of nutrients administration or deprivation to evaluate fast taste changes. This is the case of a very short-term protocol, in which the recognition threshold for sweet, sour, salty, and bitter tastants was evaluated immediately before and after the consumption of the same blend of regular or decaffeinated coffee [44]. Interestingly, in both groups of healthy participants the detection threshold for the sweet tastant was increased $(p<0.001)$ while the threshold for the bitter tastant was significantly decreased $(p<0.001)$. However, the decrease of the threshold for the bitter tastant was found to be larger in participants that did not consume coffee daily [44].

Given the interest about the impact of hunger and satiety state on taste threshold, Zverev performed a cross-over interventional, short-term, study in which 16 male participants were tested for taste threshold with a sipping technique for sweet, salty, and bitter qualities in hunger state, after 14-16 h of fasting, and in a satiated state $1 \mathrm{~h}$ after a standard dinner or lunch [48]. The recognition thresholds values for the sweet and salty substances were significantly higher during satiety state than in fasting state, while no significant difference was found for the bitter substance in fasting states and that after caloric loading. 
Following both a similar cross-over protocol and a taste threshold technique, but where the food intake was composed only of a dish of sweetened cream, Pasquet et al. did not confirm the hypothesis of Zverev of an increased sensitivity for sugars and sodium chloride in the fasted state since the within-subjects analysis found no significant threshold shift for all tastants [46].

Given the consequences of some nutrients on people's health, different studies have been conducted to evaluate the impact of food's specific components restriction on gustatory and preference in meal choice changes when the study sample is not (or not only) constituted by healthy people but by diseased or elderly subjects. Kusaba et al. conducted a short study comparing salty taste responses among 29 chronic kidney disease (CKD) patients and 11 healthy subjects, before and after 1 week of sodium restriction for the patients [49]. Although both recognition and detection thresholds for salty taste were higher in CKD patients when compared to healthy volunteers at baseline, only the average value of the recognition threshold in CKD patients was found to significantly decrease after 1 week of sodium restriction. In order to investigate whether sodium and potassium intake can lead to altered salty taste responses among adults with high blood pressure, Bolhuis et al. exposed 26 subjects with untreated upper-range prehypertension or stage 1 hypertension to a fully controlled low sodium and low potassium diet for 13 weeks [51]. The results showed that their salty taste responses were not affected over the weeks during the intervention.

Since multifactorial domains have been hypothesized as the reasons for the epidemiological increase in obesity, 20 obese free-living Japanese females, with or without Lys109Arg polymorphism (a common polymoprhism of the leptin receptor gene associated with both insulin and glucose metabolism in women with impaired glucose metabolism and obesity along sweet preference [50]), were enrolled to complete a 12-week weight-loss program, based on energy restrictions through diet and exercise, which aimed at achieving their optimal weight. Before and after the protocol study period, the subjects tasted different concentrations of sucrose [50], and no difference in changes in the sweet taste threshold between the groups ('with' versus 'without' the Lys109 allele) was found. Serum leptin levels were significantly correlated with the levels of the sweet taste threshold, which decreased significantly in a sucrose solution $(p=0.004)$.

Considering the relationship between obesity and high-fatty food consumption, multiple studies have investigated the possible impact of fatty acid on taste sensitivity. In 2011, Stewart and Keast performed a randomized cross-over dietary intervention on two groups (lean and overweight/obese) of unrestrained eater subjects: one group consumed a high-fat diet followed by a low-fat diet, and the other group consumed a low-fat diet followed by a high-fat diet over a 4 -week period [21]. The results showed that the consumption of the low-fat diet increased taste sensitivity to oleic acid (C18:1) among lean and overweight/obese subjects; conversely, the consumption of the high-fat diet significantly decreased taste sensitivity to C18:1 among lean subjects, with no change in sensitivity among overweight/obese persons.

In 2016, Newman et al. conducted more studies on how fat taste sensitivity can be influenced by fat intake: In the first study, 53 overweight/obese participants were randomized and followed either a low-fat diet or a control diet for 6 weeks [52]. In line with the previous study results, the consumption of the low-fat diet significantly decreased the C18:1 threshold ( $p=0.014$ ), while it had no significant effect on detection thresholds for sucrose $(p=0.227)$ or $\mathrm{NaCl}(p=0.558)$. In the second randomized, cross-over study, 32 participants, including 7 overweight/obese individuals, were randomly assigned to one of three different types of breakfast: a high-fat, low-fat or macronutrient balanced frittata [53]. There was no effect of breakfast type on fat taste detection thresholds for either the first or the second testing session of each day. 


\section{Discussion}

The main findings of the current scoping review are that nutritional context or dietary habits may induce different degrees of changes on taste tests. The main tastants investigated were fatty acids $[21,22,42,52,53]$, salt $[40,49,51]$, sugar $[43,47,50]$, zinc [41], alcohol [39], and glutamate [45]. Basic tastants (salty, sour, sweet and bitter) evaluation was instead performed in the only two studies evaluating on healthy volunteers the impact of fasting $[46,48]$ and of two different types of coffee [44]. The taste tests investigated, with different techniques and tastants concentrations, the detection threshold [21,39,42,44,46,47,49-53]; the recognition threshold [40,44,48,49]; the intensity rating [22,39-41,43,45,47]; and the preference [40,43] (Tables 2 and 3). Significant changes in these domains were found especially in those studies in which the nutritional intervention, dietary habits or preferences, and interventional approach on the meal load specifically encompassed the tastants included in the taste test $[20,21,39,44,51]$. This was clearly evident for those studies in which a concordance between the dietary habits or interventional meal load changes and the taste test was present: That is, works investigating the impact of changes in fatty acids levels of diet on detection threshold and intensity rating [21,22,42,52], changes of sodium chloride amount of diet on recognition — but not detection [51]—threshold [40,49], of sweet foods intake on intensity rating [47], and detection threshold [50]. Further, it appeared clear that a specific diet change may not interfere on a taste test devised for different purposes. In the experience of Wise and co-workers [47], sugar restrictions over a 3-month period only induced changes on sweet intensity and pleasantness without impacting the same scales for sodium chloride. Dalenberg et al. [43] demonstrated that the exposure to sweetened beverages did not affect the perception of basic tastants while a decrease insulin sensitivity in the healthy participants receiving sucralose combined with maltodextrin was correlated with reductions in midbrain, insular, and cingulate brain areas with BOLD-responses to sweet, but not sour, salty or savory taste as assessed with fMRI. Beyond theories postulating changes in the expression of heterodimeric taste receptor proteins [54,55], these findings may support that (i) there is a common mechanism that affects peripheral insulin release and the brain response to sweet taste; (ii) peripheral insulin affects the brain response to sweet taste or; (iii) the brain response to sweet taste affects insulin secretion [43]. However, it has been hypothesized that the decrease in insulin sensitivity induces changes in dopamine neuron regions that are important for encoding oral and post-oral reinforcing signals from food [56], which in turn can influence peripheral insulin sensitivity [43,57].

On the other hand, a specific meal load or beverage may considerably affect several tastant thresholds or ratings. This is the case of the study of Fjaeldstad and Fernandes [44] in which the detection threshold for the sweet tastant was found to be higher in a group of subjects regularly consuming coffee while the threshold for the bitter tastant was significantly lower in a group of participants regularly consuming decaffeinated coffee. Similarly, Mattes and DiMeglio [39] found that a rinse with nonalcoholic beer led to a higher sweetness intensity compared with other conditions, and to higher saltiness and sourness ratings when compared with carbonated water and beer. Moreover, the results obtained by Umabiki et al. [50] show how a weight-loss program based on a specific diet and exercise can lead to an improvement in sweet taste, which may be in part accounted for by the decrease in leptin in obese females. Noel et al. [45] came to the same conclusion in an earlier study in relation to the association between increased consumption of umami-rich foods and impaired umami perception in a free-living human population, showing that repeated exposure to umami taste diminishes perceived umami intensity. Curiously, also perceived salt taste tended to decrease across the study period. It is interesting to notice how, mainly in women, the salty taste threshold is found to be affected not only by the deprivation of its stimulus [49] but also by the exposure to umami food [45], as mentioned above, or to zinc intake [40]. This last study suggests that zinc intake plays an important role in determining salty taste acuity and shows how gustatory tests for salty taste work well when salty parameters in the diet are modified or retrospectively studied. Similarly, Kusaba et al. [49] proved that sodium restriction improved the recognition threshold for salty taste in CKD subjects 
who commonly present taste dysfunction and zinc deficiency. The literature suggests that this internally driven action on salt taste might be regulated by volume or osmosensors in various organs, or by the suppression of hormones associated with salt appetite, or an elevation in cerebrospinal fluid sodium concentrations that has been shown to reduce salt appetite [58]. However, in the study by Bolhuis et al. [51], salty taste tests did not show altered taste responses to sodium and potassium supplementation after a low sodium and low potassium diet. This was hypothesized as possibly due to many biases, including the enrollment of patients with different diseases (e.g., hypertension vs. CKD in Kusaba et al. and Bolhuis et al. study, respectively) and the subsequent administration of various drugs, previously recognized to possibly impact on salty taste threshold [49,59-63].

Collectively, these results are in line with previous literature that suggests that the appetitive tastes of different tastants may be attenuated, or preferences shifted to more intense stimuli with a diet high in the respective taste stimuli $[21,64]$. These phenomena have been attributed to a down-regulation in expression of specific subunits of sensing G-protein coupled receptors of different nutrients such as umami and fats, which in some cases, given their cross-sensitivity, may also account for a downward trend also for the sensitivity regarding other tastants (e.g., sweet taste) $[65,66]$. Equivalent associations-suggesting an adaptive relationship that is plastic with either high or low exposure to stimuli-have been reported for diets low in sugar, salt, and especially fat [21,47,67]. Examples of these findings are provided by the interventional studies conducted by Stewart and Keast [21] and Newman et al., 2016 [52,53], which collectively found that taste sensitivity to oleic acid was modulated by exposure to or deprivation of dietary fats. Fat perception decreased in lean subjects following the high-fat diet, while no change was found among overweight/obese subjects [21]. At the same time, in both lean and overweight/obese subjects, significant increases in fat perception were observed following the low-fat diet [21,52], indicating that differences in taste sensitivity to fatty acids may be a result of gustatory adaptation to a high-fat diet and may contribute to excess fat intake because of an attenuated taste response to fatty acids among individuals who habitually consume a high-fat diet $[20,52,68]$. Interestingly, thresholds for sucrose and $\mathrm{NaCl}$ did not change, indicating that the decreases in fat taste threshold were specific to the reduction in fat intake throughout the study period [52]. Further studies implemented these notions and showed that (i) higher fat intakes at the previous eating occasion were significantly associated with decreased intensity ratings [22], (ii) fat taste sensitivity is associated with the proportion of fat consumed with respect to the total energy intake rather than to the total amount of fat consumed [42], and (iii) repeated or long-term - rather than a very short-term - exposure to the tastant could be necessary to elicit a change in detection thresholds [52,53]. Based on similarities in receptor-mediated fatty acid detection within taste receptor cells and enteroendocrine cells of GI tract $[67,68]$, it is suspected that oral fatty acid detection and adaptations to fat exposure would mirror events that occur in the GI tract. Indeed, modulation of fatty acid taste receptor expression has recently been reported in rodents exposed to a high-fat diet [69], elucidating that physical changes in taste receptor expression can be induced by a high-fat diet. Considering all these data, taste tests for fatty acids may help develop personalized diets for obese or overweight people and monitor their daily fat intake with the diet.

Controversial results were obtained about the hypothesis, supporting increased sensitivity to nutrition-related tastants while fasting. Zverev et al. [48] demonstrated that recognition thresholds for sucrose and salt in healthy subjects were significantly lower during caloric deprivation than after caloric loading and that the reactivity of taste to bitter solutions was not affected by food deprivation and satiety. On the other hand, Pasquet et al. [46] failed to demonstrate any statistical difference in taste recognition thresholds between hungry and satiated states. Although these studies were acknowledged to be biased by different factors (such as lack of gender balance and different taste tests methods); open discussions about the reasons for the modulation of taste sensitivity in hungry and satiated states might be summarized as follows: (i) systemic activation of the brain during food motivation or satiety might alter the sensitivity of the central structures involved in 
the perception of taste stimuli [70]; (ii) the "tuning" efferent influences (mediated through the glossopharyngeal and lingual nerves) on gustatory receptors evoked by hunger or satiety might affect the sensitivity of the gustatory receptors [71]; and (iii) alteration of the autonomic nervous system activity during fasting might contribute to a modulation of the perception of taste stimuli [72,73]. Such findings may be relevant considering the increasing interest around fasting-mimicking diets [74].

In conclusion, the present scoping review reinforces the notions postulating that taste tests might be on one side influenced by the nutritional intervention and that, on the other one, they might be susceptible to a wide span of changes beyond the extent of tastant included in the dietary habits or the interventional meal load changes. This resulted in inhomogeneous findings and in different degrees of findings concordance, depending on the taste test technique, the nutritional intervention, or the dietary changes of the protocol. Indeed, although oral fatty acid tests demonstrated consistent results across the literature, different degrees of results of concordance have been found for other tests investigating tastants' perception changes such as sodium chloride or sugar. From a speculative point of view, this could depend on various reasons, such as the short duration of the intervention or the random type of meal load, both of which cannot be detected by taste tests; unsuitability of the taste test chosen; and the presence of underlying disorders and different biases in the observational enrolling procedures (body mass index, gender, menstrual cycle) found extensively in literature [64,75-81]. These aspects, together with individual variability, foster uncertainties in the pathophysiological factors that may collectively be influenced by such variables and finally do not pinpoint sharp borders of taste test reliability in the relative targeted conditions of food habits or changes. Thus, future, more homogeneous, studies are needed to clarify further relationships between taste and nutritional intervention.

Author Contributions: Conceptualization, A.M. and M.A.; methodology, A.M., S.M., M.F., S.C., B.M. and G.S.; formal analysis, A.M., M.A., M.F., V.C. and S.M.; data curation, A.M., M.F., S.M., N.A. and G.S.; writing—original draft preparation, A.M., M.A., S.M., M.F. and S.M.-S.; writing-review and editing, A.M., M.F., S.M., B.M., N.A., S.C., V.C., M.A. and G.S.; supervision, A.M., S.M.-S., M.F., M.A. and G.S. All authors have read and agreed to the published version of the manuscript.

Funding: This research received no external funding.

Institutional Review Board Statement: Not needed.

Informed Consent Statement: Not needed.

Data Availability Statement: The datasets generated for this study are available on request to the corresponding author.

Conflicts of Interest: The authors declare no conflict of interest.

\section{References}

1. Boesveldt, S.; De Graaf, K. The Differential Role of Smell and Taste for Eating Behavior. Perception 2017, 46, 307-319. [CrossRef]

2. Bolhuis, D.P.; Forde, C.; Cheng, Y.; Xu, H.; Martin, N.; De Graaf, C. Slow Food: Sustained Impact of Harder Foods on the Reduction in Energy Intake over the Course of the Day. PLoS ONE 2014, 9, e93370. [CrossRef]

3. Dongen, M.V.-V.; Kok, F.J.; de Graaf, C. Eating rate of commonly consumed foods promotes food and energy intake. Appetite 2011, 56, 25-31. [CrossRef]

4. Zijlstra, N.; Mars, M.; A De Wijk, R.; Westerterp-Plantenga, M.S.; De Graaf, C. The effect of viscosity on ad libitum food intake. Int. J. Obes. 2007, 32, 676-683. [CrossRef] [PubMed]

5. Forde, C.; van Kuijk, N.; Thaler, T.; de Graaf, C.; Martin, N. Texture and savoury taste influences on food intake in a realistic hot lunch time meal. Appetite 2013, 60, 180-186. [CrossRef]

6. Weijzen, P.L.G.; Smeets, P.; De Graaf, C. Sip size of orangeade: Effects on intake and sensory-specific satiation. Br. J. Nutr. 2009, 102, 1091-1097. [CrossRef]

7. Bolhuis, D.P.; Lakemond, C.M.M.; De Wijk, R.A.; Luning, P.A.; De Graaf, C. Consumption with Large Sip Sizes Increases Food Intake and Leads to Underestimation of the Amount Consumed. PLoS ONE 2013, 8, e53288. [CrossRef]

8. Bolhuis, D.; Lakemond, C.M.; de Wijk, R.A.; Luning, P.A.; de Graaf, C. Both a higher number of sips and a longer oral transit time reduce ad libitum intake. Food Qual. Preference 2014, 32, 234-240. [CrossRef] 
9. Berthoud, H.-R. Multiple neural systems controlling food intake and body weight. Neurosci. Biobehav. Rev. 2002, $26,393-428$. [CrossRef]

10. Landis, B.N.; Leuchter, I.; San Millán Ruíz, D.; Lacroix, J.S.; Landis, T. Transient hemiageusia in cerebrovascular lateral pontine lesions. J. Neurol. Neurosurg. Psychiatry 2006, 77, 680-683. [CrossRef]

11. Fromentin, G.; Darcel, N.; Chaumontet, C.; Marsset-Baglieri, A.; Nadkarni, N.; Tomé, D. Peripheral and central mechanisms involved in the control of food intake by dietary amino acids and proteins. Nutr. Res. Rev. 2012, 25, 29-39. [CrossRef] [PubMed]

12. Faipoux, R.; Tomé, D.; Gougis, S.; Darcel, N.; Fromentin, G. Proteins Activate Satiety-Related Neuronal Pathways in the Brainstem and Hypothalamus of Rats. J. Nutr. 2008, 138, 1172-1178. [CrossRef]

13. Henkin, R.I.; Powell, G.F. Increased Sensitivity of Taste and Smell in Cystic Fibrosis. Science 1962, 138, 1107-1108. [CrossRef] [PubMed]

14. Henkin, R.I.; Gill, J.R.; Bartter, F.C. Studies on taste thresholds in normal man and in patients with adrenal cortical insufficiency: The role of adrenal cortical steroids and of serum sodium concentration. J. Clin. Investig. 1963, 42, 727-735. [CrossRef]

15. Ahne, G.; Erras, A.; Hummel, T.; Kobal, G. Assessment of Gustatory Function by Means of Tasting Tablets. Laryngoscope 2000, 110, 1396-1401. [CrossRef]

16. Hummel, T.; Erras, A.; Kobal, G. A test for the screening of taste function. Rhinol. J. 1997, 35, 146-148.

17. Mueller, C.; Kallert, S.; Renner, B.; Stiassny, K.; Temmel, A.F.P.; Hummel, T.; Kobal, G. Quantitative assessment of gustatory function in a clinical context using impregnated "taste strips". Rhinol. J. 2003, 41, 2-6.

18. Landis, B.N.; Welge-Luessen, A.; Brämerson, A.; Bende, M.; Mueller, C.A.; Nordin, S.; Hummel, T. "Taste Strips"-A rapid, lateralized, gustatory bedside identification test based on impregnated filter papers. J. Neurol. 2009, 256, 242-248. [CrossRef] [PubMed]

19. Mueller, C.A.; Khatib, S.; Landis, B.N.; Temmel, A.F.P.; Hummel, T. Gustatory Function after Tonsillectomy. Arch. Otolaryngol. Head Neck Surg. 2007, 133, 668-671. [CrossRef] [PubMed]

20. Stewart, J.E.; Feinle-Bisset, C.; Golding, M.; Delahunty, C.; Clifton, P.M.; Keast, R.S.J. Oral sensitivity to fatty acids, food consumption and BMI in human subjects. Br. J. Nutr. 2010, 104, 145-152. [CrossRef]

21. E Stewart, J.; Keast, R. Recent fat intake modulates fat taste sensitivity in lean and overweight subjects. Int. J. Obes. 2011, 36, 834-842. [CrossRef]

22. Tucker, R.M.; Nuessle, T.M.; Garneau, N.; Smutzer, G.; Mattes, R.D. No Difference in Perceived Intensity of Linoleic Acid in the Oral Cavity between Obese and Nonobese Individuals. Chem. Senses 2015, 40, 557-563. [CrossRef]

23. Hinchcliffe, R. Clinical Quantitative Gustometry. Acta Oto-Laryngologica 1958, 49, 453-466. [CrossRef]

24. Nishimoto, K.; Hirota, R.; Egawa, M.; Furuta, S. Clinical Evaluation of Taste Dysfunction Using a Salt-Impregnated Taste Strip. ORL 1996, 58, 258-261. [CrossRef] [PubMed]

25. Essed, N.H.; Kleikers, S.; Van Staveren, W.A.; Kok, F.J.; De Graaf, C. No effect on intake and liking of soup enhanced with mono-sodium glutamate and celery powder among elderly people with olfactory and/or gustatory loss. Int. J. Food Sci. Nutr. 2009, 60 (Suppl. 5), 143-154. [CrossRef] [PubMed]

26. Krarup, B. Electrogustometric examinations in cerebellopontine tumors and on taste pathways. Neurology 1959, 9, 53. [CrossRef] [PubMed]

27. Schuster, B.; Iannilli, E.; Gudziol, V.; Landis, B.N. Gustatory testing for clinicians. B-ENT 2009, 5 (Suppl. 13), $109-113$.

28. Shibamori, Y.; Yamamoto, T.; Saito, T.; Manabe, Y.; Ohtsubo, T.; Yamagishi, T.; Saito, H. Morphological and functional study of regenerated chorda tympani nerves in humans. Ann. Otol. Rhinol. Laryngol. 2000, 109, 703-709. [CrossRef] [PubMed]

29. Saito, T.; Manabe, Y.; Shibamori, Y.; Yamagishi, T.; Igawa, H.; Tokuriki, M.; Fukuoka, Y.; Noda, I.; Ohtsubo, T.; Saito, H. LongTerm Follow-up Results of Electrogustometry and Subjective Taste Disorder After Middle Ear Surgery. Laryngoscope 2001, 111, 2064-2070. [CrossRef]

30. Schoenfeld, M.; Neuer, G.; Tempelmann, C.; Schüßler, K.; Noesselt, T.; Hopf, J.-M.; Heinze, H.-J. Functional magnetic resonance tomography correlates of taste perception in the human primary taste cortex. Neuroscience 2004, 127, 347-353. [CrossRef]

31. Ogawa, H.; Wakita, M.; Hasegawa, K.; Kobayakawa, T.; Sakai, N.; Hirai, T.; Yamashita, Y.; Saito, S. Functional MRI Detection of Activation in the Primary Gustatory Cortices in Humans. Chem. Senses 2005, 30, 583-592. [CrossRef] [PubMed]

32. Small, D.M.; Jones-Gotman, M.; Zatorre, R.J.; Petrides, M.; Evans, A.C. Flavor processing: More than the sum of its parts. NeuroReport 1997, 8, 3913-3917. [CrossRef] [PubMed]

33. Just, T.; Pau, H.W.; Bombor, I.; Guthoff, R.F.; Fietkau, R.; Hummel, T. Confocal microscopy of the Peripheral Gustatory System: Comparison between Healthy Subjects and Patients Suffering from Taste Disorders during Radiochemotherapy. Laryngoscope 2005, 115, 2178-2182. [CrossRef]

34. Just, T.; Pau, H.W.; Witt, M.; Hummel, T. Contact Endoscopic Comparison of Morphology of Human Fungiform Papillae of Healthy Subjects and Patients with Transected Chorda Tympani Nerve. Laryngoscope 2006, 116, 1216-1222. [CrossRef] [PubMed]

35. Tricco, A.C.; Lillie, E.; Zarin, W.; O’Brien, K.K.; Colquhoun, H.; Levac, D.; Moher, D.; Peters, M.; Horsley, T.; Weeks, L.; et al. PRISMA Extension for Scoping Reviews (PRISMA-ScR): Checklist and Explanation. Ann. Intern. Med. 2018, 169, 467-473. [CrossRef] [PubMed]

36. Peters, M.D.J. In no uncertain terms: The importance of a defined objective in scoping reviews. JBI Database Syst. Rev. Implement. Rep. 2016, 14, 1-4. [CrossRef] 
37. Munn, Z.; Peters, M.D.J.; Stern, C.; Tufanaru, C.; McArthur, A.; Aromataris, E. Systematic review or scoping review? Guidance for authors when choosing between a systematic or scoping review approach. BMC Med. Res. Methodol. 2018, 18, 1-7. [CrossRef]

38. Ouzzani, M.; Hammady, H.; Fedorowicz, Z.; Elmagarmid, A. Rayyan-A web and mobile app for systematic reviews. Syst. Rev. 2016, 5, 1-10. [CrossRef] [PubMed]

39. Mattes, R.D.; DiMeglio, D. Ethanol perception and ingestion. Physiol. Behav. 2001, 72, 217-229. [CrossRef]

40. Noh, H.; Paik, H.-Y.; Kim, J.; Chung, J. Salty Taste Acuity Is Affected by the Joint Action of $\alpha$ ENaC A663T Gene Polymorphism and Available Zinc Intake in Young Women. Nutrients 2013, 5, 4950-4963. [CrossRef] [PubMed]

41. Zdilla, M.J.; Saling, J.R.; Starkey, L.D. Zinc sulfate taste acuity reflects dietary zinc intake in males. Clin. Nutr. ESPEN 2016, 11, e21-e25. [CrossRef] [PubMed]

42. Costanzo, A.; Orellana, L.; Nowson, C.; Duesing, K.; Keast, R. Fat Taste Sensitivity Is Associated with Short-Term and Habitual Fat Intake. Nutrients 2017, 9, 781. [CrossRef] [PubMed]

43. Dalenberg, J.R.; Patel, B.P.; Denis, R.; Veldhuizen, M.; Nakamura, Y.; Vinke, P.C.; Luquet, S.; Small, D.M. Short-Term Consumption of Sucralose with, but Not without, Carbohydrate Impairs Neural and Metabolic Sensitivity to Sugar in Humans. Cell Metab. 2020, 31, 493-502. [CrossRef]

44. Fjaeldstad, A.W.; Fernandes, H.M. Chemosensory Sensitivity after Coffee Consumption Is Not Static: Short-Term Effects on Gustatory and Olfactory Sensitivity. Foods 2020, 9, 493. [CrossRef] [PubMed]

45. A Noel, C.; Finlayson, G.; Dando, R. Prolonged Exposure to Monosodium Glutamate in Healthy Young Adults Decreases Perceived Umami Taste and Diminishes Appetite for Savory Foods. J. Nutr. 2018, 148, 980-988. [CrossRef] [PubMed]

46. Pasquet, P.; Monneuse, M.-O.; Simmen, B.; Marez, A.; Hladik, C.-M. Relationship between taste thresholds and hunger under debate. Appetite 2006, 46, 63-66. [CrossRef] [PubMed]

47. Wise, P.M.; Nattress, L.; Flammer, L.J.; Beauchamp, G.K. Reduced dietary intake of simple sugars alters perceived sweet taste intensity but not perceived pleasantness. Am. J. Clin. Nutr. 2016, 103, 50-60. [CrossRef]

48. Zverev, Y.P. Effects of caloric deprivation and satiety on sensitivity of the gustatory system. BMC Neurosci. 2004, 5, 5. [CrossRef] [PubMed]

49. Kusaba, T.; Mori, Y.; Masami, O.; Hiroko, N.; Adachi, T.; Sugishita, C.; Sonomura, K.; Kimura, T.; Kishimoto, N.; Nakagawa, H.; et al. Sodium restriction improves the gustatory threshold for salty taste in patients with chronic kidney disease. Kidney Int. 2009, 76, 638-643. [CrossRef] [PubMed]

50. Umabiki, M.; Tsuzaki, K.; Kotani, K.; Nagai, N.; Sano, Y.; Matsuoka, Y.; Kitaoka, K.; Okami, Y.; Sakane, N.; Higashi, A. The Improvement of Sweet Taste Sensitivity with Decrease in Serum Leptin Levels during Weight Loss in Obese Females. Tohoku J. Exp. Med. 2010, 220, 267-271. [CrossRef] [PubMed]

51. Bolhuis, D.P.; Gijsbers, L.; De Jager, I.; Geleijnse, J.M.; De Graaf, K. Encapsulated sodium supplementation of 4weeks does not alter salt taste preferences in a controlled low sodium and low potassium diet. Food Qual. Preference 2015, 46, 58-65. [CrossRef]

52. Newman, L.P.; Bolhuis, D.P.; Torres, S.J.; Keast, R.S. Dietary fat restriction increases fat taste sensitivity in people with obesity. Obesity 2016, 24, 328-334. [CrossRef] [PubMed]

53. Newman, L.P.; Torres, S.J.; Bolhuis, D.P.; Keast, R.S. The influence of a high-fat meal on fat taste thresholds. Appetite 2016, 101, 199-204. [CrossRef]

54. Chen, K.; Yan, J.; Suo, Y.; Li, J.; Wang, Q.; Lv, B. Nutritional status alters saccharin intake and sweet receptor mRNA expression in rat taste buds. Brain Res. 2010, 1325, 53-62. [CrossRef]

55. Maliphol, A.B.; Garth, D.J.; Medler, K.F. Diet-Induced Obesity Reduces the Responsiveness of the Peripheral Taste Receptor Cells. PLoS ONE 2013, 8, e79403. [CrossRef] [PubMed]

56. Tellez, L.A.; Han, W.; Zhang, X.; Ferreira, T.; Perez, I.O.; Shammah-Lagnado, S.J.; Pol, A.N.V.D.; De Araujo, I.E. Separate circuitries encode the hedonic and nutritional values of sugar. Nat. Neurosci. 2016, 19, 465-470. [CrossRef]

57. ter Horst, K.W.; Lammers, N.M.; Trinko, R.; Opland, D.M.; Figee, M.; Ackermans, M.T.; Booij, J.; Munckhof, P.V.D.; Schuurman, P.R.; Fliers, E.; et al. Striatal dopamine regulates systemic glucose metabolism in humans and mice. Sci. Transl. Med. 2018, 10, eaar3752. [CrossRef] [PubMed]

58. Denton, D.; McKinley, M.J.; Nelson, J.F.; Osborne, P.; Simpson, J.; Tarjan, E.; Weisinger, R.S. Species differences in the effect of decreased CSF sodium concentration on salt appetite. J. de Physiol. 1984, 79, 499-504.

59. Beauchamp, G.K.; Bertino, M.; Burke, D.; Engelman, K. Experimental sodium depletion and salt taste in normal human volunteers. Am. J. Clin. Nutr. 1990, 51, 881-889. [CrossRef]

60. Teow, B.H.; Di Nicolantonio, R.; Morgan, T.O. Sodium Chloride Preference and Recognition Threshold in Normotensive Subjects on High and Low salt Diet. Clin. Exp. Hypertens. 1985, 7, 1681-1695. [CrossRef]

61. Uzu, T.; Kimura, G. Diuretics Shift Circadian Rhythm of Blood Pressure From Nondipper to Dipper in Essential Hypertension. Circulation 1999, 100, 1635-1638. [CrossRef]

62. Uzu, T.; Kazembe, F.S.; Ishikawa, K.; Nakamura, S.; Inenaga, T.; Kimura, G. High Sodium Sensitivity Implicates Nocturnal Hypertension in Essential Hypertension. Hypertension 1996, 28, 139-142. [CrossRef]

63. Golik, A.; Modai, D.; Weissgarten, J.; Cohen, N.; Averbukh, Z.; Sigler, E.; Zaidenstein, R.; Shaked, U. Hydrochlorothiazideamiloride causes excessive urinary zinc excretion. Clin. Pharmacol. Ther. 1987, 42, 42-44. [CrossRef] [PubMed]

64. Sartor, F.; Donaldson, L.; Markland, D.A.; Loveday, H.; Jackson, M.; Kubis, H.-P. Taste perception and implicit attitude toward sweet related to body mass index and soft drink supplementation. Appetite 2011, 57, 237-246. [CrossRef] 
65. Martin, C.; Passilly-Degrace, P.; Gaillard, D.; Merlin, J.-F.; Chevrot, M.; Besnard, P. The Lipid-Sensor Candidates CD36 and GPR120 Are Differentially Regulated by Dietary Lipids in Mouse Taste Buds: Impact on Spontaneous Fat Preference. PLoS ONE 2011, 6, e24014. [CrossRef]

66. Zhao, G.Q.; Zhang, Y.; Hoon, M.A.; Chandrashekar, J.; Erlenbach, I.; Ryba, N.J.; Zuker, C.S. The Receptors for Mammalian Sweet and Umami Taste. Cell 2003, 115, 255-266. [CrossRef]

67. Cartoni, C.; Yasumatsu, K.; Ohkuri, T.; Shigemura, N.; Yoshida, R.; Godinot, N.; Le Coutre, J.; Ninomiya, Y.; Damak, S. Taste Preference for Fatty Acids Is Mediated by GPR40 and GPR120. J. Neurosci. 2010, 30, 8376-8382. [CrossRef]

68. Laugerette, F.; Passilly-Degrace, P.; Patris, B.; Niot, I.; Febbraio, M.; Montmayeur, J.-P.; Besnard, P. CD36 involvement in orosensory detection of dietary lipids, spontaneous fat preference, and digestive secretions. J. Clin. Investig. 2005, 115, 3177-3184. [CrossRef] [PubMed]

69. Zhang, X.-J.; Zhou, L.-H.; Ban, X.; Liu, D.-X.; Jiang, W.; Liu, X.-M. Decreased expression of CD36 in circumvallate taste buds of high-fat diet induced obese rats. Acta Histochem. 2011, 113, 663-667. [CrossRef]

70. Sudakov, K.V. Brain neuronal mechanisms of motivation and reinforcement: Systemic organization of behavior. Integr. Physiol. Behav. Sci. 1993, 28, 396-407. [CrossRef]

71. Plata-Salamán, C.R. Regulation of Hunger and Satiety in Man. Dig. Dis. 1991, 9, 253-268. [CrossRef] [PubMed]

72. Sulimov, A.V. The hunger dominant in man and the reactions of the autonomic nervous system. Zhurnal vysshei nervnoi deiatelnosti imeni IP Pavlova 1993, 43, 707-712.

73. Uryvaev Iu, V.; Zverev Iu, P. A stimulated shift in heart rhythm stability as a condition for CNS activation and stimulus perception. Zhurnal vysshei nervnoi deiatelnosti imeni IP Pavlova 1991, 41, 828-830. [CrossRef] [PubMed]

74. Fanti, M.; Mishra, A.; Longo, V.D.; Brandhorst, S. Time-Restricted Eating, Intermittent Fasting, and Fasting-Mimicking Diets in Weight Loss. Curr. Obes. Rep. 2021, 10, 70-80. [CrossRef]

75. Fischer, M.E.; Cruickshanks, K.J.; Ms, C.R.S.; Pinto, A.; Klein, B.E.K.; Klein, R.; Nieto, F.J.; Pankow, J.; Huang, G.-H.; Snyder, D.J. Taste intensity in the Beaver Dam Offspring Study. Laryngoscope 2013, 123, 1399-1404. [CrossRef] [PubMed]

76. Noel, C.; Dando, R. The effect of emotional state on taste perception. Appetite 2015, 95, 89-95. [CrossRef]

77. Martin, L.; Sollars, S.I. Contributory role of sex differences in the variations of gustatory function. J. Neurosci. Res. 2017, 95, 594-603. [CrossRef] [PubMed]

78. A Noel, C.; Cassano, P.A.; Dando, R. College-Aged Males Experience Attenuated Sweet and Salty Taste with Modest Weight Gain. J. Nutr. 2017, 147, 1885-1891. [CrossRef] [PubMed]

79. Donaldson, L.F.; Bennett, L.; Baic, S.; Melichar, J.K. Taste and weight: Is there a link? Am. J. Clin. Nutr. 2009, 90, 800S-803S. [CrossRef]

80. Faas, M.M.; Melgert, B.N.; De Vos, P. A Brief Review on How Pregnancy and Sex Hormones Interfere with Taste and Food Intake. Chemosens. Percept. 2009, 3, 51-56. [CrossRef]

81. Choo, E.; Dando, R. The Impact of Pregnancy on Taste Function. Chem. Senses 2017, 42, 279-286. [CrossRef] [PubMed] 